Research article

\title{
Intrauterine environments and breast cancer risk: meta-analysis and systematic review
}

\author{
Sue Kyung Park1,2,3, Daehee Kang ${ }^{1,3}$, Katherine A McGlynn², Montserrat Garcia-Closas², \\ Yeonju Kim ${ }^{1}$, Keun Young Yoo ${ }^{1,4}$ and Louise A Brinton ${ }^{2}$
}

\author{
${ }^{1}$ Department of Preventive Medicine, Seoul National University College of Medicine, Yeongeon-dong, Jongro-gu, Seoul 110-799, Seoul, Republic of \\ Korea \\ 2Division of Cancer Epidemiology and Genetics, National Cancer Institute, National Institutes of Health, Executive Blvd, Rockville, Maryland 20892- \\ 7234, USA \\ ${ }^{3}$ Cancer Research Institute, Seoul National University, Yeongeon-dong, Jongro-gu, Seoul 110-799, Seoul, Republic of Korea \\ ${ }^{4}$ National Cancer Center, Madu1-Dong, Ilsandong-Gu, Goyang-Si, Gyeonggi-Do 410-769, Republic of Korea
}

Corresponding author: Sue Kyung Park, suepark@snu.ac.kr

Received: 20 Jul 2007 Revisions requested: 23 Aug 2007 Revisions received: 30 Sep 2007 Accepted: 21 Jan 2008 Published: 21 Jan 2008

Breast Cancer Research 2008, 10:R8 (doi:10.1186/bcr1850)

This article is online at: http://breast-cancer-research.com/content/10/1/R8

(c) 2008 Park et al.; licensee BioMed Central Ltd.

This is an open access article distributed under the terms of the Creative Commons Attribution License (http://creativecommons.org/licenses/by/2.0), which permits unrestricted use, distribution, and reproduction in any medium, provided the original work is properly cited.

\begin{abstract}
Introduction Various perinatal factors, including birth weight, birth order, maternal age, gestational age, twin status, and parental smoking, have been postulated to affect breast cancer risk in daughters by altering the hormonal environment of the developing fetal mammary glands. Despite ample biologic plausibility, epidemiologic studies to date have yielded conflicting results. We investigated the associations between perinatal factors and subsequent breast cancer risk through meta-analyses.
\end{abstract}

Methods We reviewed breast cancer studies published from January 1966 to February 2007 that included data on birth weight, birth order, maternal age, gestational age, twin status, and maternal or paternal smoking. Meta-analyses using random effect models were employed to summarize the results.

Results We found that heavier birth weights were associated with increased breast cancer risk, with studies involving five categories of birth weight identifying odds ratios (ORs) of 1.24
(95\% confidence interval [Cl] 1.04 to 1.48 ) for $4,000 \mathrm{~g}$ or more and $1.15(95 \% \mathrm{Cl} 1.04$ to 1.26$)$ for $3,500 \mathrm{~g}$ to $3,999 \mathrm{~g}$, relative to a birth weight of 2,500 to $2,599 \mathrm{~g}$. These studies provided no support for a J-shaped relationship of birthweight to risk. Support for an association with birthweight was also derived from studies based on three birth weight categories (OR 1.15 [95\% Cl 1.01 to 1.31 ] for $\geq 4,000 \mathrm{~g}$ relative to $<3,000 \mathrm{~g}$ ) and two birth weight categories (OR 1.09 [95\% Cl 1.02 to 1.18] for $\geq 3,000 \mathrm{~g}$ relative to $<3,000 \mathrm{~g}$ ). Women born to older mothers and twins were also at some increased risk, but the results were heterogeneous across studies and publication years. Birth order, prematurity, and maternal smoking were unrelated to breast cancer risk.

Conclusion Our findings provide some support for the hypothesis that in utero exposures reflective of higher endogenous hormone levels could affect risk for development of breast cancer in adulthood.

\section{Introduction}

Intrauterine environmental exposures to endogenous or exogenous hormones, notably estrogens, may influence the subsequent development of breast cancer in offspring [1]. During pregnancy, levels of circulating estrogens and other hormones with growth-enhancing properties are at least 10 times higher than those in nonpregnant women, with increases seen with advancing gestational age [2-4]. The hypothesis that breast cancer in daughters may be influenced by the intrauterine environment is receiving increased attention [5]. Perinatal factors, including birth weight, birth order, maternal age, gestational age, twin status, and parental smoking, have been postulated as risk factors for breast cancer through altered hormonal influences on the developing fetal mammary glands [1]. Despite ample biologic plausibility, this hypothesis is difficult to evaluate directly [5], and previous epidemiologic studies have reported conflicting results $[6,7]$.

Here we review the epidemiologic studies that have assessed the association between perinatal factors and breast cancer

$\overline{\mathrm{Cl}}=$ confidence interval; $\mathrm{OR}=$ odds ratio; $\mathrm{RR}=$ relative risk. 
risk in daughters. A meta-analytical approach was applied in order to clarify further the possible role played by the intrauterine environment in the etiology of breast cancer.

\section{Materials and methods Identification of studies}

The data retrieved for the systematic review were based on searches of all published papers, letters, abstracts, and review articles on birth weight, birth order, maternal age, gestational age, twin status, and maternal or paternal smoking and breast cancer using the MEDLINE database from January 1966 through February 2007. We used keywords combining text words, with terms for six perinatal factors combined with terms for breast cancer (Table 1). We also manually searched the reference lists of all studies that fulfilled the inclusion criteria for further relevant publications. Articles were included in our systematic review if they fulfilled the following three criteria: the exposure status of at least one of six perinatal risk factors of interest was compared with nonexposure status; the outcome focused on the daughter's breast cancer morbidity or mortality using an epidemiologic study design (case-control design, data linkage study, or cohort study design); and the article was written in English language. We excluded animal studies, investigations focusing on male breast cancer, reviews, and studies that did not provide separate relative risks for breast cancer. We also excluded studies if odds ratios (ORs) or relative risks (RRs) were not specifically provided, raw data were not available for calculation of risks, or the emphasis of analyses was on hazard ratios or standardized incidence ratios.

\section{Statistical analyses}

For the purposes of meta-analysis, birth weight was classified in three different ways: five categories $(<2,500 \mathrm{~g}, 2,500$ to $2,999 \mathrm{~g}$ [referent], 3,000 to $3,499 \mathrm{~g}, 3,500$ to $3,999 \mathrm{~g}$, and $\geq 4,000 \mathrm{~g}$ ); three categories $(<3,000 \mathrm{~g}$ [referent], 3,001 to $3,999 \mathrm{~g}$, and $\geq 4,000 \mathrm{~g}$ ); and two categories $(<3,000 \mathrm{~g}$ [or $\leq 3,000 \mathrm{~g}$; referent] and $\geq 3,000 \mathrm{~g}$ [or $>3,000 \mathrm{~g}]$ ). Birth order was examined using two different categorical schemes: 1 (referent) versus $\geq 2$; and 1 (referent), 2 to 4 , and $\geq 5$. Maternal age was classified into three categories: $<25$ years old (referent), 25 to 29 years old, and $\geq 30$ years old. Gestational age was also analyzed in two ways: $\leq 36$ weeks versus $\geq 37$ weeks (referent); and $\leq 32$ weeks versus $\geq 33$ weeks (referent). To examine twin status, three classification schemes were employed: twin versus singleton (referent); monozygotic twin (or sister twins if zygosity was not reported) versus singleton (referent); and dizygotic twin (or sister-brother twins if zygosity was not reported) versus singleton (referent). Maternal or paternal smoking was considered as follows: no smoking during pregnancy (referent) versus smoking during pregnancy. If the criteria utilized in an article were slightly different from our criteria, then we included the data and described the difference in a footnote.
ORs and 95\% confidence intervals (Cls) were recalculated from published frequency tables of individual studies using the Mantel-Haenszel common OR estimate. However, the reported OR $(95 \% \mathrm{Cl})$ was used when the published studies did not provide further details as to the frequencies of the exposure variables. If the manuscript reported the results after performing a stratified analysis, then we re-calculated the crude OR by combining across strata. A random-effects model was used to obtain summary ORs and 95\% Cls.

Heterogeneity was assessed by heterogeneity test using Cochran $\mathrm{Q}$ statistics [8]. Publication bias was assessed according to the Egger regression asymmetry test, and the Begg and Mazumdar adjusted rank correlation tests $[9,10]$. The Egger test is a simple linear regression of the natural log of ORs or RRs against its precision (the inverse of its standard error) [10]. The Begg and Mazumdar rank correlation test reports the rank correlation (Kendall's tau) between the standardized effect size and the standard errors of these effects. If asymmetry is caused by publication bias, then we would expect that high standard errors (small studies) would be associated with larger effect sizes (ORs or RRs) or low standard errors (large studies) would be associated with smaller effect sizes [9]. The Begg and Mazumdar test makes fewer assumptions than does the Egger test, but it is insensitive to many types of bias (lower power) that the Egger test is sensitive to [11].

When significant heterogeneity or publication bias was found, we performed subgroup analyses by study design (case-control study versus cohort study), and the source of information (data linkage versus self-report) to assess the impact on between-study variations (heterogeneity). Many of the largescale studies, especially cohort studies, were published after 2000; thus, we classified publication years into before 2000 versus 2000 or later in order to assess publication biases associated with small study sizes. Few studies focused on either Asians or African-Americans, and so it was not possible to examine ethnicity effects. All statistical analyses were conducted using STATA (Version 8.2 [special edition]; Stata Corp., College Station, TX, USA).

\section{Results}

We identified 34 studies that assessed the association between birth weight and breast cancer risk (Table 2): 19 case-control studies (eight population based, three nested, six record linkage based, and two twin-based) and 15 cohort studies (seven population based and eight record linkage based). Many studies showed positive association between heavier birth weight and breast cancer risk [12-31], and some of the studies observed stronger effects among younger $(<45$ years) or premenopausal women [14,22,29,30]. In contrast, studies observing no association [32-41] or a negative one [42-45] also have been reported. Additionally, some authors reported a J-shaped relationship between birth weight and 
breast cancer risk [12,14,15,18,25,33,35,37,45], particularly for early-onset cancers [18].

Among 34 studies of birth weight and breast cancer, we selected studies that employed the same categories of birth weight. To evaluate whether a J-shaped relationship existed, we grouped birth weight into more than three categories. The findings of meta-analysis of eight studies that utilized five categories of birth weight $(<2,500,2,500$ to $2,999,3,000$ to $3,499,3,500$ to 3,999 , and $\geq 4,000 \mathrm{~g})$ and 11 studies that used three categories $(<3,000,3,000$ to 3,999 , and $\geq 4,000$ g) are shown in Figures 1 and 2. To include more studies, we also categorized birthweights as $<3,000 \mathrm{~g}$ (or $\leq 3,000 \mathrm{~g}$ ) and $\geq 3,000 \mathrm{~g}$ (or $>3,000 \mathrm{~g}$; Figure 3). Sixteen studies among all 34 studies were included in the meta-analyses for birth weight and breast cancer: seven studies [13,14,18,32,33,35,44] were included in the all three meta-analyses; four studies $[22,23,27,39]$ were included in the two of the three meta-analyses; and five studies were included in only one meta-analysis $[12,16,28,34,38]$. There was no significant heterogeneity across studies ( $P$ _Q test $>0.05$ for all categories). In the fivecategory meta-analysis, ORs were $1.11(95 \% \mathrm{Cl} 0.90$ to 1.33$)$ for birth weight $<2,500 \mathrm{~g}, 1.11$ (0.99 to 1.25 ) for 3,000 to $3,499 \mathrm{~g}, 1.15$ (1.04 to 1.26 ) for 3,500 to $3,999 \mathrm{~g}$, and 1.24 (1.04 to 1.48 ) for $\geq 4,000 \mathrm{~g}$ relative to the referent category of 2,500 to $2,999 \mathrm{~g}$. In the three-category meta-analysis, ORs were 1.06 (95\% Cl 0.98 to 1.14 ) for 3,000 to $3,999 \mathrm{~g}$ and 1.15 ( 1.01 to 1.31 ) for $\geq 4,000 \mathrm{~g}$ relative to the referent category of $<3,000 \mathrm{~g}$. In the two-category meta-analysis, ORs were $1.09(95 \% \mathrm{Cl} 1.02$ to 1.18$)$ for the category of $>3,000$ $\mathrm{g}$ (or $\geq 3,000 \mathrm{~g}$ ) relative to the referent category of $\leq 3,000 \mathrm{~g}$ (or $<3,000 \mathrm{~g}$ ).

We identified 17 studies (15 case-control and two cohort) that assessed the association between birth order and breast cancer risk (Table 3). Eight of the studies reported an inverse relationship $[14,20,31,35,36,42,46,47]$. Some studies found significantly lower risks for second or later born children versus first-born children $[31,46]$. Some studies found significantly or marginally significantly reduced risk among women

Figure 1

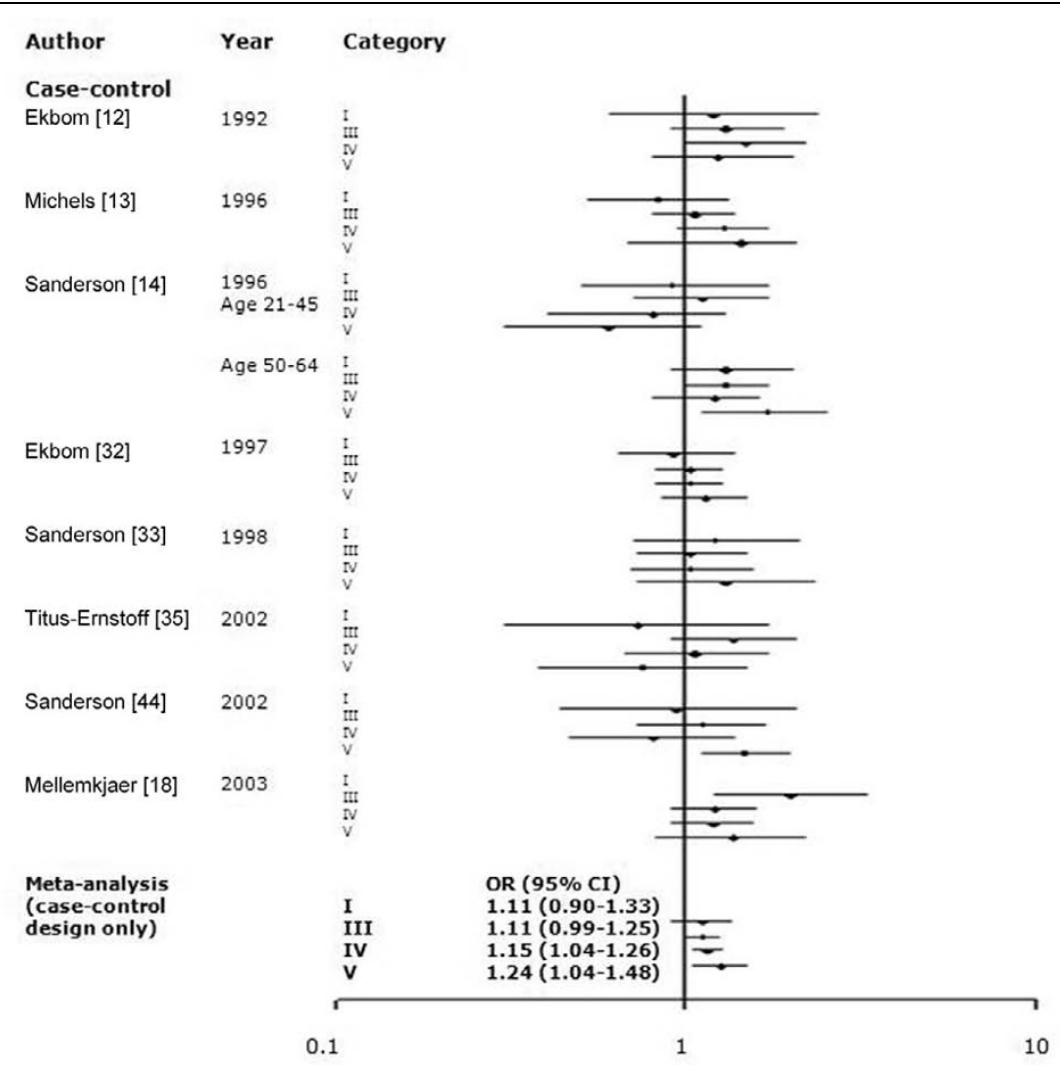

Meta-analysis of the association between birth weight (five categories) and risk for breast cancer. The tests for homogeneity and for publication bias in the studies analyzed are as follows. Category I (birth weight $<2,500 \mathrm{~g}$ ) versus reference: $\mathrm{Q}=9.66$ ( 8 degrees of freedom), $P=0.29 ; B$ Begg test, $P=0.75$; Egger test, $P=0.66$. Category II $(2,500$ to $2,999 \mathrm{~g})$ is the reference. Category III $(3,000$ to $3,499 \mathrm{~g})$ versus reference: $\mathrm{Q}=6.53(8$ degrees of freedom), $P=0.59$; Begg test, $P=0.25$; Egger test, $P=0.46$. Category IV $(3,500$ to $3,999 \mathrm{~g})$ versus reference: $\mathrm{Q}=4.17$ ( 8 degrees of freedom), $P=0.84$; Begg test, $P=0.60$; Egger test, $P=0.93$. Category $\mathrm{V}(\geq 4,000 \mathrm{~g})$ versus reference: $\mathrm{Q}=11.18$ ( 8 degrees of freedom), $P=$ 0.19 ; Begg test, $P=0.25$; Egger test, $P=0.30$. ${ }^{1}$ We used adjusted odds ratios (ORs) for meta-analysis because the numbers of cases and controls were not represented in the original article. $\mathrm{Cl}$, confidence interval. 


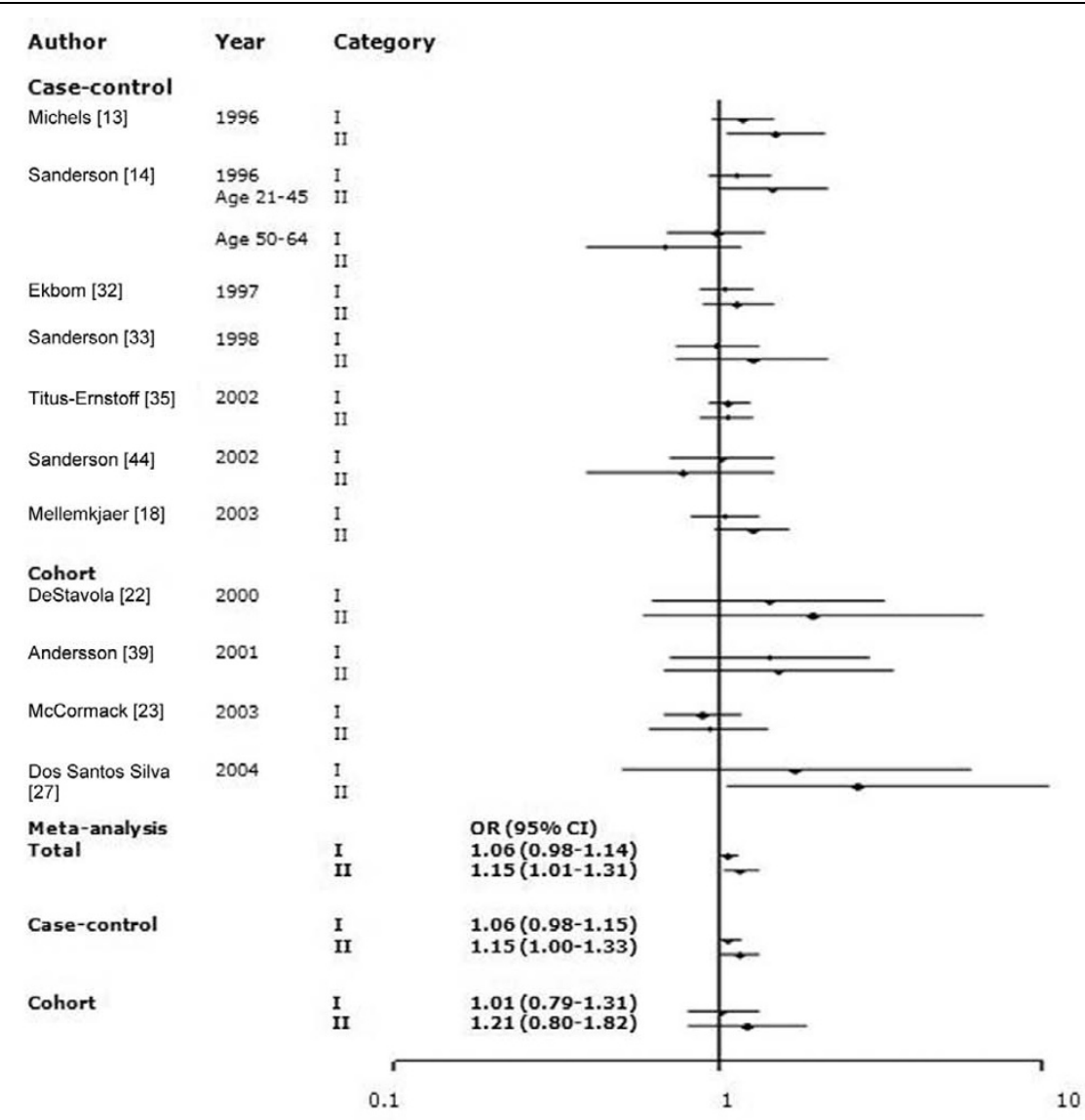

Meta-analysis of the association between birth weight (three categories) and risk for breast cancer. The tests for homogeneity and for publication bias in the studies analyzed are as follows. Category I (birth weight 3,000 to 3,999 g) versus reference ( $<3,000 \mathrm{~g}$ ): $Q=4.97$ ( 11 degrees of freedom), $P=0.93$; Begg test, $P=0.54$; Egger test, $P=0.27$. Category II ( $\geq 4,000 \mathrm{~g}$ ) versus reference: $\mathrm{Q}=13.44$ (11 degrees of freedom), $P=0.27$; Begg test, $P=0.54$; Egger test, $P=0.53$. Cl, confidence interval; $\mathrm{OR}$, odds ratio.

whose birth had been preceded by the birth of at least five siblings $[20,35]$. Other several studies noted an increased risk associated with higher birth order [15,37,48,49], whereas some studies failed to observe such an association $[12,18,32,50]$. One study did not supply the estimated risk but describe the $P$ value by the mean difference of birth order [51].

For the meta-analysis, we included 14 studies (13 case-control studies and one cohort) that used two birth order categories: 1 (referent) and $\geq 2$. There was significant heterogeneity across all studies $\left(P_{-} \mathrm{Q}\right.$ test $\left.<0.01\right)$, although there was no significant heterogeneity across the case-control studies $\left(P \_\mathrm{Q}\right.$ test $\left.=0.90\right)$. As shown in Figure 4, there was no difference in risk according to birth order across all studies (OR 0.97 [95\% Cl 0.91 to 1.04]) or within the case control studies (OR 0.99 [95\% Cl 0.94 to 1.04]). We calculated the crude odds ratio from the cohort study [31], and the result was very different from the summary OR (calculated crude OR 0.28 [95\% Cl 0.21 to 0.36]). The results of all case-control studies were near null, whereas the cohort study found a significant risk reduction in birth orders of 2 or greater. We also examined the seven studies that classified individuals according to three birth order levels ( 1 [referent], 2 to $4, \geq 5$; Figure. 4). There was significant heterogeneity across studies (all of which were case-control studies) for the highest birth order category $\left(P \_\mathrm{Q}\right.$ test $=0.03$ ) Women with a birth order of $\geq 5$ were at nonsignificantly reduced risk compared with first-born women (OR 0.88 [95\% Cl 0.75-1.01]). There was no difference in risk for women of birth orders 2 to 4 (OR 0.97 [95\% Cl 0.91-1.03]).

We identified 28 studies (22 case-control and six cohort) that assessed the association between maternal age and breast cancer risk (Table 4). Seven studies observed modestly increased risks for daughters born to older mothers $[15,31,32,36,42,46,52]$. A pattern of slight decrease after modest increase in risk was found in five other studies [50,5356]. Fourteen studies, however, no association was observed $[12,14,18,20,35,37,38,47,49,57-60]$. Two studies did not estimate the risks $[51,61]$.

In our meta-analyses, we included the 18 studies that reported categorical data and examined three age categories $(\leq 24$ [ref- 
Figure 3

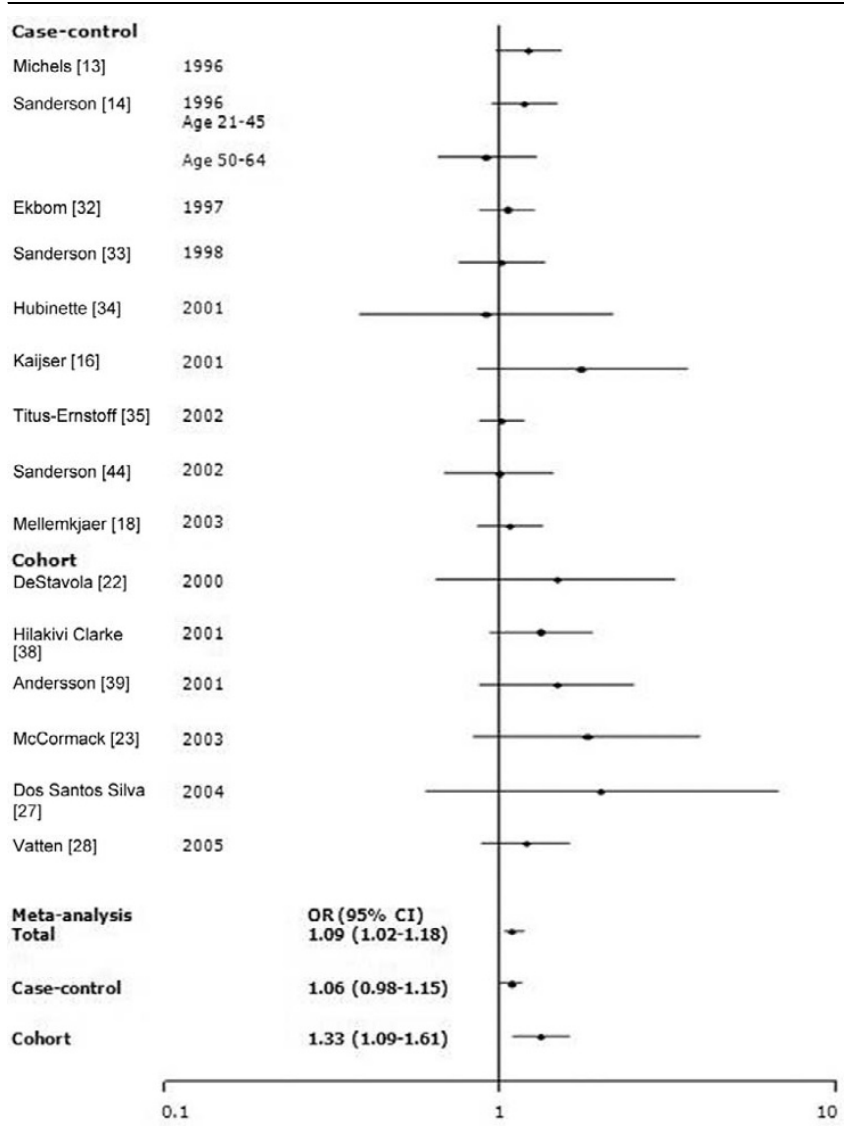

Meta-analysis of the association between birth weight (two categories) and risk for breast cancer. The tests for homogeneity and for publication bias in the studies analyzed are as folows. Reference $(<3,000 \mathrm{~g}$ [or $\leq 3,000 \mathrm{~g}$ ) versus $\geq 3,000 \mathrm{~g}$ (or $>3,000 \mathrm{~g}$ ): $\mathrm{Q}=11.57$ ( 15 degrees of freedom), $P=0.93$; Begg test, $P=0.15$; Egger test, $P=0.50$. Cl, confidence interval; OR, odds ratio.

erent], 25 to 29 , and $\geq 30$ years; Figure 5). There was, however, significant study heterogeneity $\left(P_{-} \mathrm{Q}\right.$ test $<0.01$ for 25 to 29 years and for $\geq 30$ years). Heterogeneity was also present across case-control studies and studies published after $2000\left(P \_\mathrm{Q}\right.$ test $\left.<0.01\right)$. The ORs $(95 \% \mathrm{Cl})$ were 1.18 (1.05 to 1.11$)$ for 25 to 29 years and 1.23 (1.07 to 1.15$)$ for $\geq 30$ years across all studies.

We identified 15 studies (10 case-control and five cohort) that assessed the association between prematurity and breast cancer risk (Table 5). Most studies did not observe a significant relationship [13-16,20,25,29,31,33,40,42,45]. Two studies found that extreme prematurity was associated with an increased risk (OR 3.96 [95\% Cl 1.46 to 10.81] for $\leq 32$ weeks relative to $\geq 33$ weeks [32], and SIR (standardized incidence ratio) 6.7 [95\% Cl 1.4 to 19.5] for <31 weeks [62]). In contrast, another study [34] found that longer gestation was associated with a significantly increased risk (OR $8.4[95 \% \mathrm{Cl}$ 1.3 to 54.4 ] for $\geq 40$ weeks relative to $\leq 32$ weeks).
There was no significant heterogeneity across studies $(P-Q$ test $=0.55)$, whereas we found no association between prematurity ( $\leq 36$ weeks) and risk (OR $1.04[95 \% \mathrm{Cl} 0.92$ to 1.18]; Figure 6). However, a strong publication bias was observed $(P$-Egger test $=0.03$ and $P$-Begg test $=0.11$; Figure 7). A significant publication bias occurred because three studies with smaller standard errors of log RR $[15,16,34]$ reported RRs near 1.0, whereas five studies with larger standard errors $[13,20,31,33,45]$ reported substantially reduced RRs. When the analysis was performed for extreme prematurity ( $\leq 32$ weeks), heterogeneity was also evident across the studies ( $P$-Q test $=0.04)$, and the association was not significant (OR 1.20 [95\% $\mathrm{Cl} 0.74$ to 1.95$]$ ).

We examined 13 studies (eight case-control and five cohort) that assessed the association between twin status and risk (Table 6). Most studies identified a slightly increased risk among twins $[15,31,32,43,45,58,63-66]$, with five studies demonstrating significant associations $[31,58,64-66]$. In contrast, some studies observed a slightly reduced risk $[14,20,67]$, with one of the risks being marginally significant [67]. Seven studies $[20,32,58,63,65,66]$ had information on zygosity. Of these studies, two $[58,63]$ used the twins' sex as a proxy for zygosity. For monozygotic twins, a reduction in risk was significant in one study [68]. Most studies failed to observe an association $[20,32,58,63,65,66]$. Three studies reported a significantly increased risk associated with being a dizygotic twin $[58,65,66]$, whereas other studies reported no association $[20,32,63,67]$ (Figure 8).

The $\mathrm{Q}$ test for heterogeneity was not significant $(P-\mathrm{Q}$ test $=$ 0.13 ), and the meta-analysis of 13 studies examining twin status (without regard to zygosity) found an OR of $1.22(95 \% \mathrm{Cl}$ 1.01 to 1.11). There was no evidence of any publication bias ( $P$-Egger test or $P$-Begg test $>0.1)$. There were little evidence of heterogeneity $(P-Q$ test $>0.1$ for monozygotic or dizygotic twins), and breast cancer risk was not significantly increased among either monozygotic (OR 0.95 [95\% $\mathrm{Cl} 0.85$ to 1.07]) or dizygotic (OR 1.17 [95\% Cl 0.99 to 1.37]) twins, albeit based on limited statistical power. In subgroup analysis by study design, cohort studies identified significantly increased risk (OR 1.23 [95\% Cl 1.00 to 1.11]) for breast cancer in twins versus singletons, with no study heterogeneity $(P-Q$ test $=0.07$ ). Case-control studies showed no association with twin status (OR 1.39 [95\% Cl 0.91 to 1.12]). There was no evidence of any publication bias ( $P$-Egger test or $P$-Begg test $>0.05$ ) among the case-control or cohort studies. In subgroup analysis by study design and zygosity, there were no heterogeneity in studies $(P-\mathrm{Q}$ test $>0.1)$. In subgroup analysis by study year, significant heterogeneity by publication year was identified $(P=0.01)$, and the OR $(95 \% \mathrm{Cl})$ for studies published before 2000 was 1.06 (0.97 to 1.47), whereas the OR (95\% $\mathrm{Cl}$ ) for studies published in 2000 or later was 1.27 (1.03 to 1.58). 


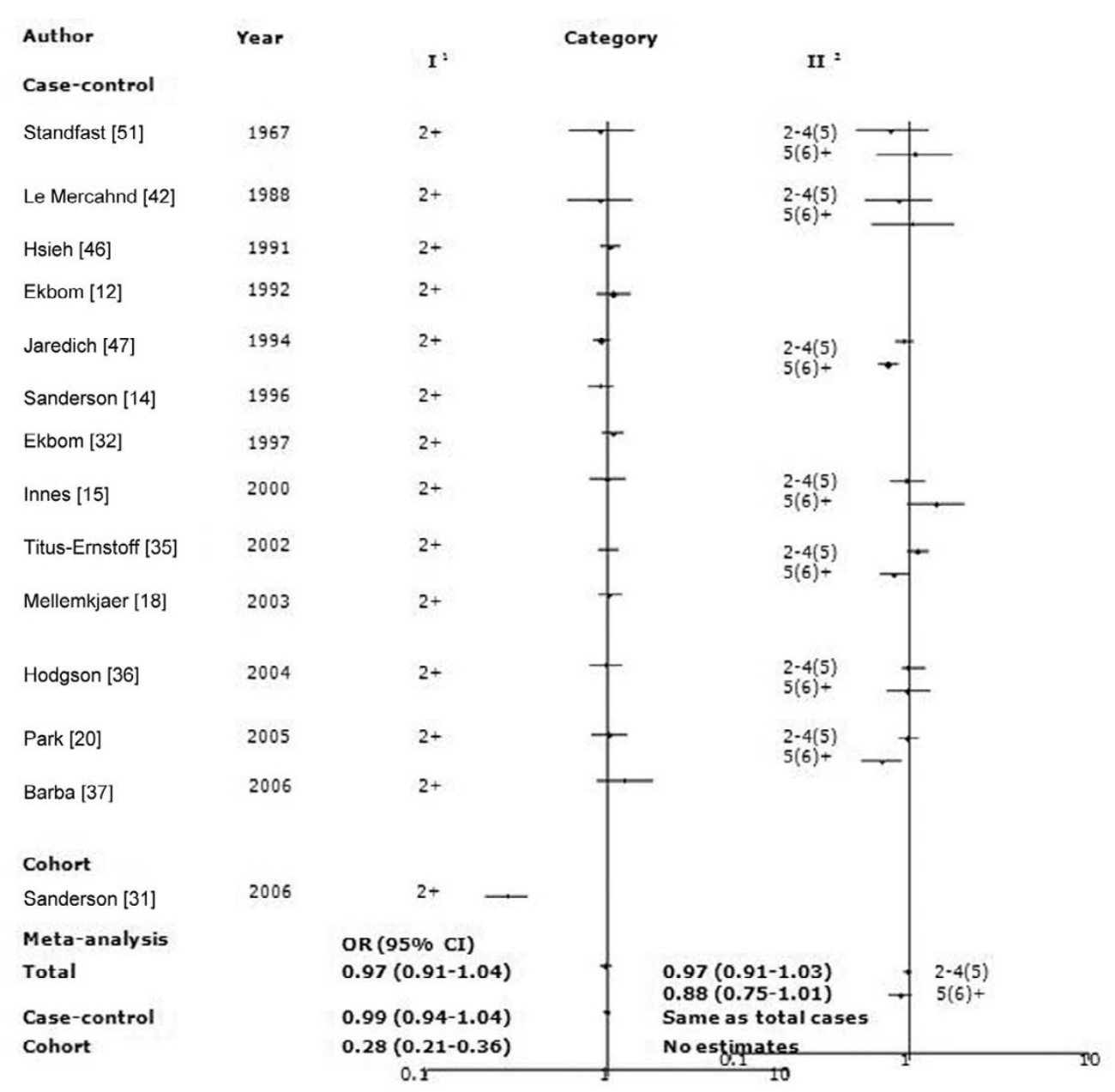

Meta-analysis of the association between birth order and risk for breast cancer. The tests for homogeneity and for publication bias in the studies analyzed are as follows. Category I (birth order 2+) versus reference (birth order 1): $\mathrm{Q}=87.79$ (13 degrees of freedom), $P<0.01 ; B$ egg test, $P=0.44$; Egger test, $P=0.46$. Category II (birth order $5+$ and 2 to 4 ) versus reference: $\mathrm{Q}=4.56$ (6 degrees of freedom), $P=0.60 ; B e g g$ test, $P=0.37$; Egger test, $P=0.44$. Category II (birth order $\geq 6,2$ to 5 ) versus reference: $\mathrm{Q}=14.42$ (6 degrees of freedom), $P=0.60 ; \mathrm{Begg}$ test, $P=0.37 ;$ Egger test, $P=0.44 .{ }^{1}$ Category I of birth order was $2+$ vs $1 .{ }^{2}$ Category II of birth order was composed of two conditions: $5+$ and 2 to 4 ; and $\geq 6$ and 2 to 5 vs 1 . ${ }^{3}$ We used adjusted odds ratios (ORs) for meta-analysis because the numbers of cases and controls were not represented in the original article. $\mathrm{Cl}$, confidence interval.

We identified nine studies that assessed the association between maternal or paternal smoking and risk (Table 7). Two cohort studies reported nonsignificantly reduced risks associated with maternal smoking (OR 0.49 [95\% $\mathrm{Cl} 0.29$ to 1.03$]$ [68]; OR 0.8 [95\% Cl 0.5 to 1.1] [31]), whereas a case-control study [43] identified a significant positive association (ageadjusted OR 2.7 [95\% Cl 1.1 to 6.3]), although its crude OR was not statistically significant (OR 1.1 [95\% Cl 0.7 to 1.7]). The majority of studies, however, identified no associations with maternal $[14,20,33,35,58,69]$ or paternal $[20,35,69]$ smoking during pregnancy.

There was no heterogeneity or publication bias $(P$-Q test $>$ $0.05, P$-Egger test and $P$-Begg test $>0.1$ among all studies, case-control or cohort). The meta-analysis for maternal smok- ing (Figure 9) found no significant association with risk (OR 0.98 [95\% Cl 0.86 to 1.13$]$ ), although cohort studies $[40,68]$ noted a significant negative association with maternal smoking (OR 0.59 [95\% Cl 0.41 to 0.85$]$ ).

\section{Discussion}

The main finding of our meta-analysis was that heavier birth weight was associated with increased breast cancer risk (18\% increased risk for the heaviest weight). Twin status was associated with 1.2-fold higher risk for breast cancer relative to a singleton birth. Although we found some evidence of increased risk associated with older maternal age (OR 1.16 for maternal age $\geq 30$ years), there were heterogeneous findings across study designs. 
Figure 5

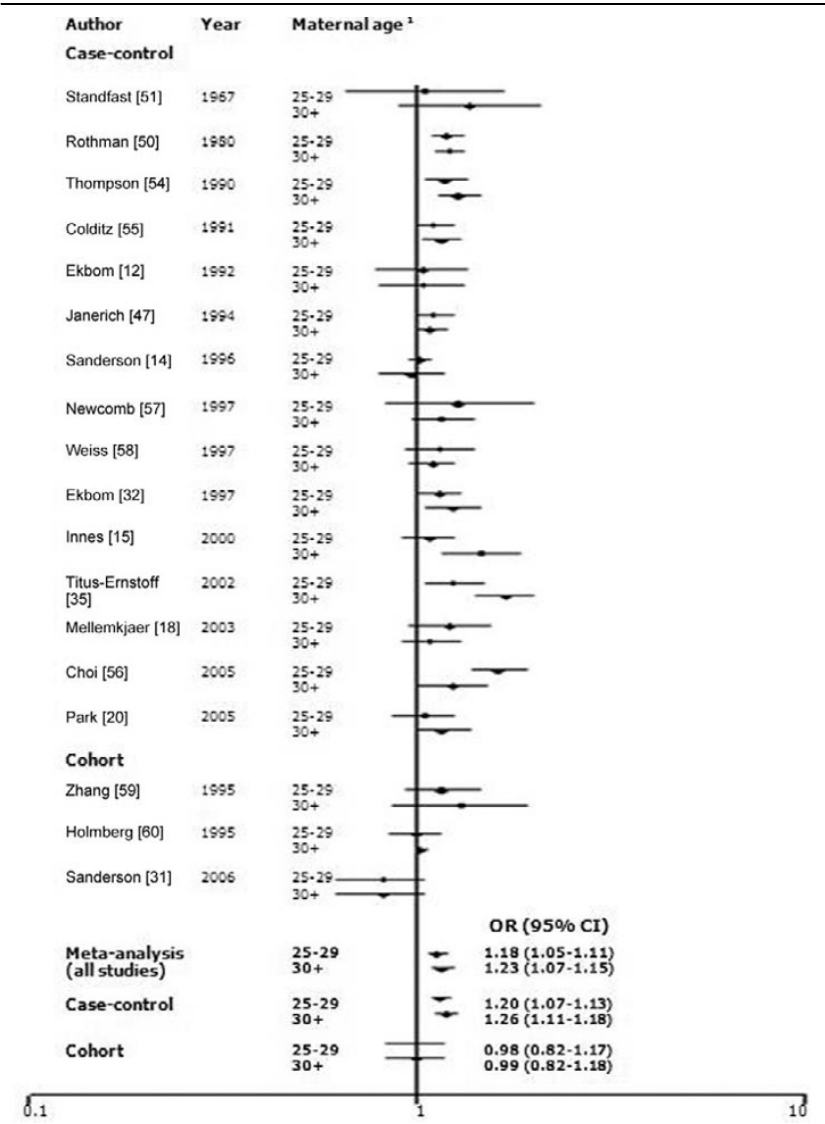

Meta-analysis for the association between maternal age and the risk of breast cancer. The tests for homogeneity and for publication bias in the studies analyzed are as follows. Maternal age 25 to 29 years: $\mathrm{Q}=$ 39.40 (17 degrees of freedom), $P<0.01$; Begg test, $P=0.85$; Egger test, $P=0.38$, Maternal age $30+$ years: $\mathrm{Q}=67.34$ (17 degrees of freedom), $P<0.01$; Begg test, $P=0.88$; Egger test, $P=0.07$. ${ }^{1}$ The reference for maternal age is $\leq 24$ years old. $\mathrm{Cl}$, confidence interval; OR, odds ratio.

Most studies identified an increased risk for breast cancer with heavier birth weight, with the association being particularly strong for premenopausal or early-onset breast cancers $[14,22,29,30]$. Our result was similar to the findings of a recent meta-analysis of 26 studies, which revealed that high birth weight was associated with a RR of 1.23 and restricted to premenopausal women (OR 1.25 [95\% Cl 1.14 to 1.38 ) [70]. This analysis grouped birth weight into two categories (classified into high and low birth weight in each study, regardless of specific weight in terms of grams), preventing evaluation of dose-response relationships. We did in fact observe evidence of a dose-response relationship of risk with birth weight, although this was based on a relatively small number of studies involving three or four categories.

Although some studies identified a J-shaped relationship between birth weight and breast cancer risk $[12,14,15,18,25,33,35,37,45]$, others failed to note an increased risk associated with very low birth weights. A recent study involving 3,066 breast cancer patients and 106,504 comparison individuals in a Danish cohort also found no elevated risk among those with very low birth weights [71]. Similarly, our meta-analysis provided little evidence of increased risk for very low birth weights.

Although the mechanisms underlying the association between high birth weight and breast cancer risk remain unclear, it has been suggested that heavier birth weights may result from increased in utero exposuresto factors such as insulin-like growth factor-I or estrogens [72-76]. These substances may act as mitogens by increasing the likelihood of genetic mutations $[75,77]$. However, several studies have failed to find any correlation between umbilical cord estrogen levels and birth weight $[78,79]$. One study, however, reported a significant positive relationship with estriol [80]. Further studies should be undertaken to assist in the resolution of these conflicting data.

Our analysis found no association of breast cancer risk with birth orders between 2 and 4 , but we did note a somewhat reduced risk associated with higher birth orders (at least 5), although the results were heterogeneous across studies. Biologically, pregnancy estrogen levels appear to be higher during first pregnancies and decline in successive pregnancies [81]. Furthermore, cord blood levels of estradiol, estrone, and progesterone are lower for later born than first born children [82]. These findings suggest that the reduced risk associated with higher birth orders may relate to lower estrogen levels. However, evidence supporting birth order as a risk factor for breast cancer is limited, with further investigations needed to evaluate dose-response relationships more fully.

In our meta-analysis, we found some evidence that having been born to an older mother was associated with higher breast cancer risk, although the results were heterogeneous across studies. Our data failed to support the previous studies that suggested a J-shaped relationship between maternal age and breast cancer risk. It was previously suggested that older maternal age may have an adverse effect on the primordial mammary gland of their daughters because of altered hormonal profiles [37] or may linked to the epigenetic change of mtDNA which can lead to breast carcinogenesis by oocyte inheritance [83]. However, the two studies that examined pregnancy estrogen levels according to maternal age found that both total estrogen and estradiol levels were lowest in youngest mothers ( $<20$ years of age), highest in those aged 20 to 24 years, and intermediate in mothers over 25 years of age $[78,81]$. Thus, it remains unclear from both our meta-analysis as well as from biologic data whether maternal age is a proxy for estrogen or estradiol exposure to fetus. Although it has been suggested that older paternal age may cause germ cell mutations, previous epidemiologic studies have failed to support an association $[35,20,69,82,84,85]$. Because the 
Figure 6

\begin{tabular}{|c|c|c|c|c|c|c|c|c|c|}
\hline Author & Year & Category : & & Author & Year & Category ${ }^{2}$ & & & \\
\hline Case-control & & & & Case-control & & & & & \\
\hline Michels [13] & 1996 & $\leq 36$ & & Le Merchand [42] & 1988 & $\leq 32$ & & _ & \\
\hline Sanderson [33] & 1998 & $\leq 36$ & 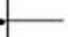 & Ekbom [32] & 1997 & $\leq 32$ & & & 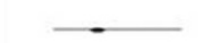 \\
\hline Innes [15] & 2000 & $\leq 36$ & - - & Innes [15] & 2000 & $\leq 32$ & & & - \\
\hline Hubinette [34] & 2001 & $\leq 36$ & - & Hubinette [34] & 2001 & $\leq 32$ & & & 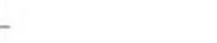 \\
\hline $\begin{array}{l}\text { Innes \& Byers } \\
\text { [45] }\end{array}$ & 2004 & $\leq 36$ & 1 & $\begin{array}{l}\text { Innes \& Byers } \\
{[45]}\end{array}$ & 2004 & $\leq 32$ & & & - \\
\hline Park [20] & 2005 & $\leq 36$ & - & & & & & & \\
\hline Cohort & & & & Meta-analysis & & & OR $(95 \% \mathrm{CI})$ & & \\
\hline Kaijser [16] & 2001 & $\leq 36$ & . & & & & & & \\
\hline Sanderson [31] & 2006 & $\leq 36$ & & & & 0.01 & 0.1 & 1 & 10 \\
\hline Meta-analysis & & OR $(95 \% \mathrm{CI})$ & & & & & & & \\
\hline Total & & $1.04(0.92-1.18)$ & & & & & & & \\
\hline
\end{tabular}

Meta-analysis of studies assessing the association of prematurity and risk for breast cancer. The tests for homogeneity and for publication bias in the studies analyzed are as follows. Category $36+: \mathrm{Q}=5.91$ (7 degrees of freedom), $P=0.55$; Begg test, $P=0.11$; Egger test, $P=0.03$. Category $32+: \mathrm{Q}=10.10$ (4 degrees of freedom), $P=0.04$; Begg test, $P=0.09$; Egger test, $P=0.40$. ${ }^{1}$ Category of prematurity (week): $\leq 36$ versus $\geq 37$ (reference). ${ }^{2}$ Category of prematurity (week): $\leq 32$ versus $\geq 33$ (reference). $\mathrm{Cl}$, confidence interval; OR, odds ratio.

purpose of this study was to evaluate whether the intrauterine hormone environment affects subsequent breast cancer risk, our meta-analysis did not include paternal age.

We observed no association between prematurity and breast cancer risk. Biologically, women having abruptio placentae or an extremely premature birth ( $<32$ week) have been shown to have elevated levels of human chorionic gonadotropin and $\alpha$ -

Figure 7

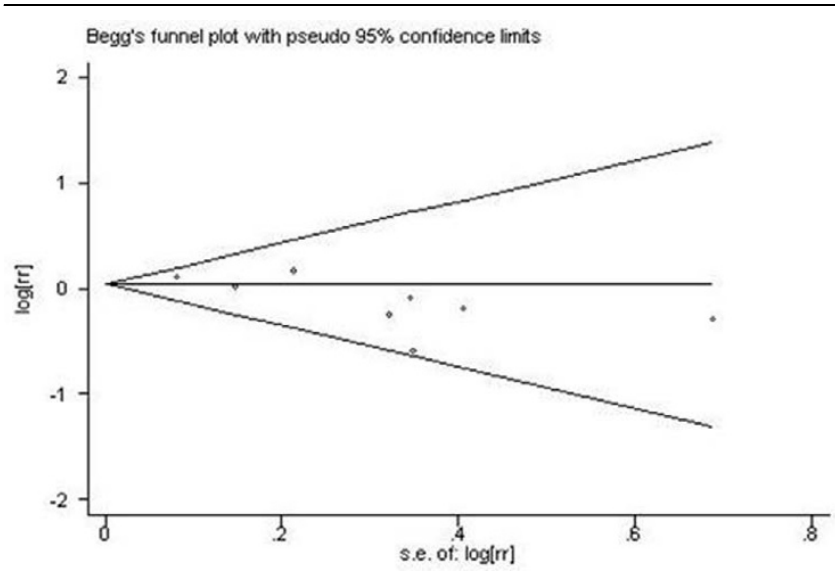

Begg's funnel plot for publication bias in meta-analysis of premature birth and breast cancer risk. Premature birth (gestational age $\leq 36$ weeks) was compared with gestational age $\geq 37$ weeks. Egger test, $P=$ 0.03 ; Begg test, $P=0.11$. rr, relative risk; s.e., standard error. fetoprotein, which could inhibit the differentiation of stem cells in human breast tissue cells [15]. Gestational age is related to birth weight, of course, because birth weights in infants born prematurely are lower than those in infants born at term [13].

Twin pregnancies are associated with an approximate doubling of estrogen levels compared with singleton pregnancies $[86,87]$. Dizygotic twin pregnancies have elevated levels of estrogens and gonadotropins [88-90]. It has therefore been postulated that twins, especially dizygotic twins, could be at an elevated risk for breast cancer. In general, our results did not support differences in risk between monozygotic and dizygotic twins, and there was evidence that risk estimates published after 2000 were qualitatively different from those of earlier studies.

Studies of parental smoking, especially maternal smoking, and daughter's breast cancer risk have yielded inconsistent results. Biologically, maternal smoking, rather than paternal smoking, has a greater impact on the fetus. In the meta-analytic results, both factors failed to exhibit a significant association with risk. Some studies have reported that maternal smoking in pregnancy reduces serum estrogen levels [91,92]. A recent experimental study reported that both estradiol-17 $\beta$ levels and progesterone:estradiol-17 $\beta$ ratios were reduced in pregnant mice exposed to cigarette smoke [93]. However, the relevance of these findings to humans is unclear. 
Figure 8

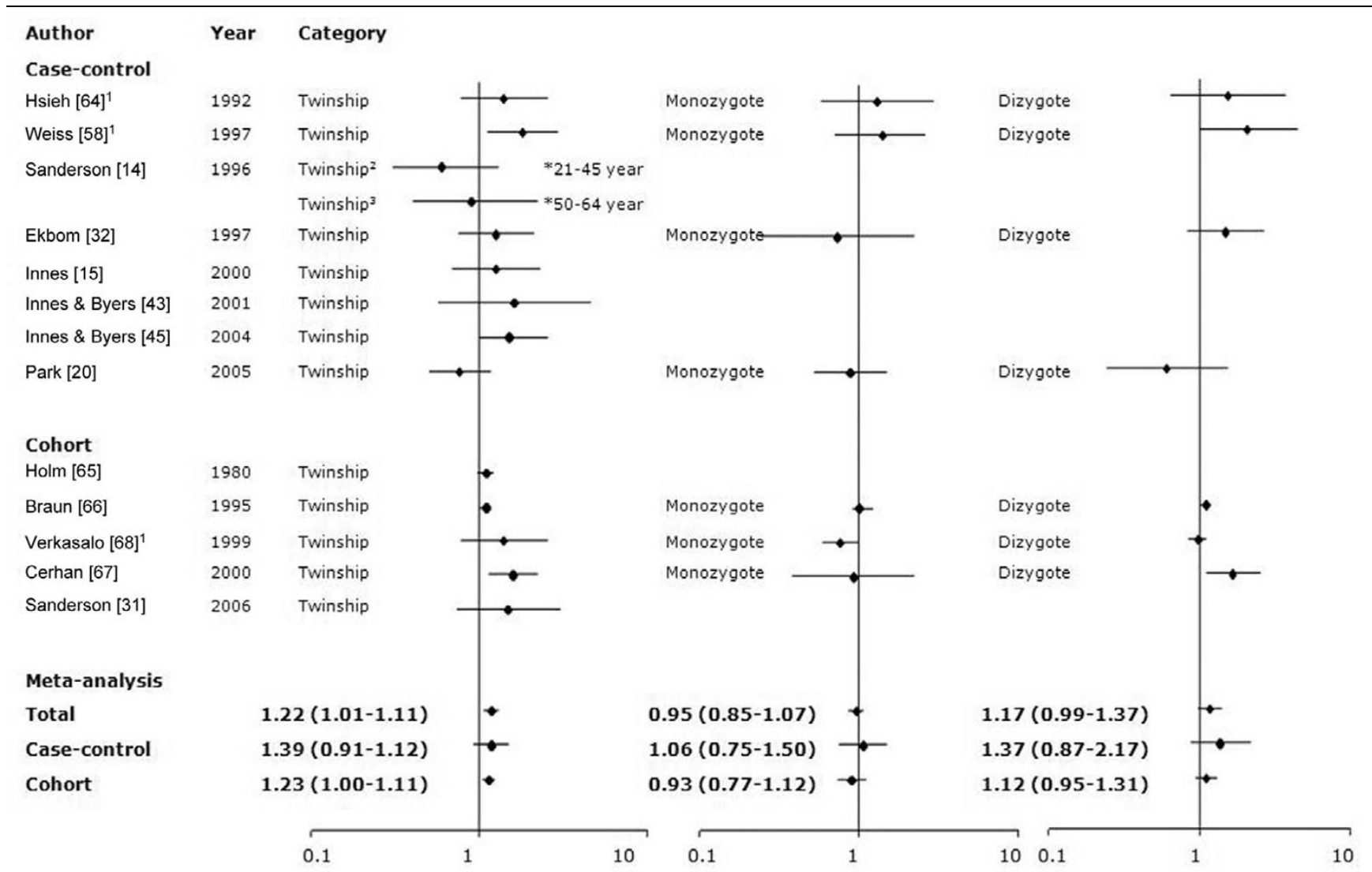

Meta-analysis for the association between twinship and risk for breast cancer. The tests for homogeneity and for publication bias in the studies analyzed are as follows. Twinship: $\mathrm{Q}=18.79$ (13 degrees of freedom), $P=0.13$; Begg test, $P=0.78$; Egger test, $P=0.24$. Monozygote twin: $\mathrm{Q}=$ 5.79 (6 degrees of freedom), $P=0.45$; Begg test, $P=0.55$; Egger test, $P=0.85$. Dizygote twin: $\mathrm{Q}=12.53$ ( 6 degrees of freedom), $P=0.06$; Begg test, $P=1.0$; Egger test, $P=0.3$. ${ }^{1}$ The authors used the female twins as the proxy for the monozygote twin and the female twin with male twin as the proxy for the dizygote twin. ${ }^{2}$ Women aged 21 to 45 years. ${ }^{3}$ Women aged 50 to 64 years. $\mathrm{Cl}$, confidence interval; OR, odds ratio.

These meta-analyses are based on results from studies involving heterogeneous designs and methodology. We did note between-study heterogeneity for the associations of birth order, maternal age, and twin status. To resolve the heterogeneous findings, we considered the influence of study design and the date of study publication on the results by subgroup analyses. However, heterogeneity in studies could only be explained partially.

Effects of maternal age, birth order, prematurity (cut-off value 32 weeks), and maternal smoking were found to be heterogeneous across study designs, but birth weight and twinning were comparable. Self-reported measures of perinatal factors may be vulnerable to misclassification biases, with differential or nondifferential effects [94,95]. Because studies based on data linkage to medical records have a lower chance of misclassification bias, we conducted subgroup meta-analyses stratified by source of information (data linkage versus selfreport) and found no substantial differences in the results. Although the completeness of records is a critical factor in evaluating biases in studies based on data linkage, most papers did not provide details about the completeness of records. We also conducted subgroup meta-analyses stratified by publication year. Only twin status exhibited significant heterogeneity according to publication year $(<2000$ versus $\geq 2000$ ).

Our findings may be somewhat inflated because of our dependence on crude rather than adjusted ORs or RRs. A possible misclassification bias for zygosity might have resulted in studies that used sex as a proxy for zygosity [96]. Because this bias would probably attenuate associations, additional investigations are needed to determine the extent of any true association of risk with twin status.

\section{Conclusion}

It has been hypothesized that certain perinatal factors, including birth weight and order, twin pregnancies, prematurity, maternal age, and smoking, may reflect higher estrogenic environments in utero, thereby increasing the subsequent risk of breast cancer. Findings of an increase in breast cancer risk among daughters exposed to diethylstilbestrol in utero sup- 
Figure 9

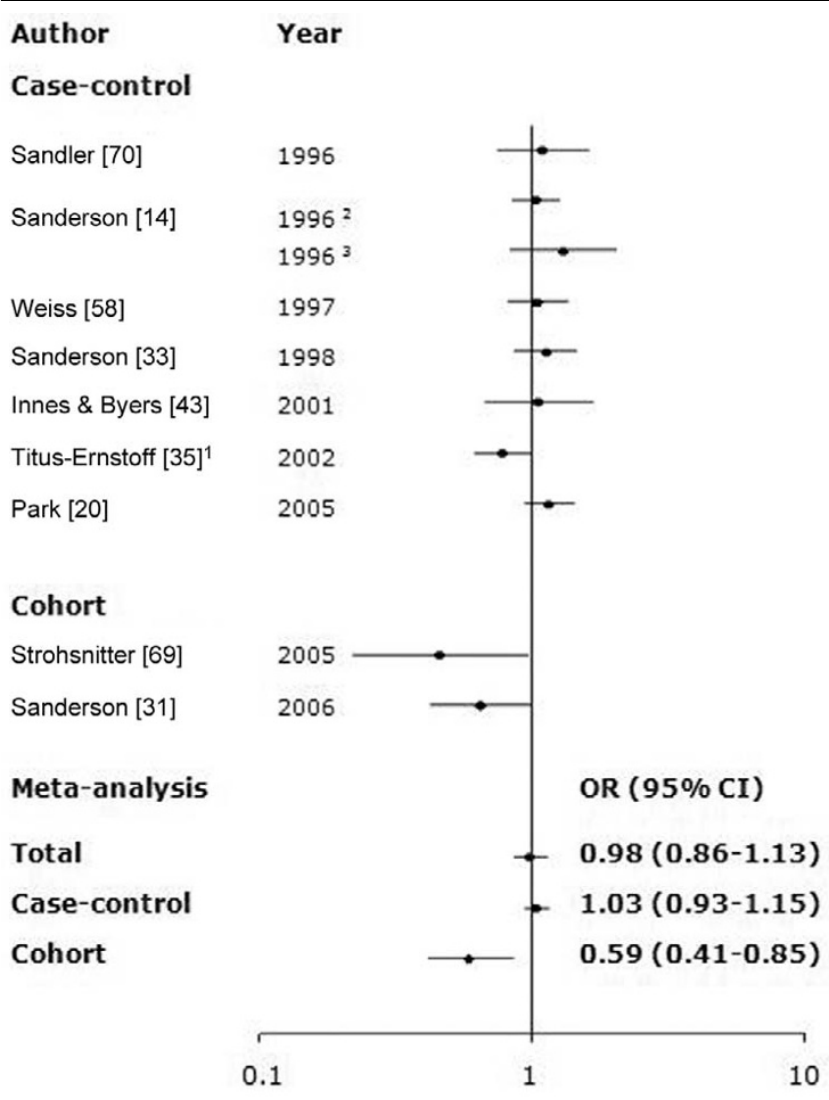

Meta-analysis for the association of maternal smoking during pregnancy with risk for subsequent breast cancer. The tests for homogeneity and for publication bias in the studies analyzed are as follows: $\mathrm{Q}=$ 16.90 (9 degrees of freedom), $P=0.06$; Begg test, $P=0.59$; Egger test, $P=0.31$. ' Titus-Ernstoff and coworkers [35] classified three categories: nonparental smoking, paternal or maternal smoking only or both parents smoking during pregnancy. The odds ratios (ORs) of father smoking on breast cancer risk was almost unity (OR 1.0, 95\% confidence intrval $[\mathrm{Cl}] 0.9$ to 1.1$)$. Thus, in this study, the mother smoking and both parents smoking versus nonparental smoking can be considered to the maternal smoking versus no maternal smoking. ${ }^{2}$ Women aged 21 to 45 years. ${ }^{3}$ Women aged 50 to 64 years. ports this hypothesis $[97,98]$. Although the current meta-analysis found evidence that higher birth weights are associated with increased breast cancer risk, older maternal age and twin status were less convincingly related, and birth order and prematurity appeared unrelated. Greater birth weights have been attributed to higher maternal estrogens levels, which could affect fetal development [72-74] through epigenetic modifications of breast stem cells $[1,99,100]$. Although our findings regarding birth weight support the hypothesis that higher estrogen exposures in utero may be involved in the subsequent development of breast cancer, further biologic data are needed to elucidate the relationship fully.

\section{Competing interests}

The authors declare that they have no competing interests.

\section{Authors' contributions}

SKP collected and selected the all of breast cancer studies, analyzed the data in the study, drafted the manuscript, critically revised the manuscript for important intellectual content, and takes responsibility for the study concept and design, the integrity of the data, and the accuracy of the data analysis. DK participated in design of the study, drafting of the manuscript and interpretation of results, and critically revised the manuscript for important intellectual content. KAM was responsible for the study concept and design, interpreted the findings, and revised the manuscript for important intellectual content. MGC participated in the interpretation of the data and revision of the manuscript. YK was involved in data analysis and revision for important intellectual content. KYY contributed to interpreting the findings and critically revised the manuscript for important intellectual content. LAB led conception and design of the study, the analysis and interpretation of the findings, and revision to the manuscript, and obtained part funding for this research. All authors read and approved the final manuscript. 
Table 1

Search terms used in systematic review

\begin{tabular}{ll}
\hline Subject & Search term \\
\hline Breast neoplasm & Breast neoplasms, subsequent breast neoplasm, breast neoplasm and daughter \\
Birth weight & Cirth weight, birthweight, birth size \\
Birth order & Birth order, birth rank \\
Maternal age & Maternal age, mother's age, parental age \\
Gestational age & Gestational age, preterm, prematurity, abruption placenta, pre-eclampsia, eclampsia \\
Twinship & Twin, twining, multiple births, multiple pregnancy, monozygote twin, dizygote twin, \\
Parental smoking & Maternal smoking, mother's smoking, paternal smoking, father's smoking, parental smoking \\
Others & Prenatal factors, perinatal factors, intrauterine environment, intrauterine factor, In-utero exposure \\
\end{tabular}


Breast Cancer Research Vol 10 No 1 Park et al.

Table 2

Studies assessing the association of birth weight and the risk for breast cancer

\begin{tabular}{|c|c|c|c|c|c|c|c|c|c|}
\hline $\begin{array}{l}\text { Type of } \\
\text { study }\end{array}$ & Ref. & Year & Design & Cases & $\begin{array}{l}\text { Controls } \\
\text { (or cohort) }\end{array}$ & $\begin{array}{l}\text { Country/ } \\
\text { place of study }\end{array}$ & Birthweight (g) & OR $(95 \% \mathrm{Cl})$ & Comments \\
\hline \multirow{29}{*}{$\begin{array}{l}\text { Case- } \\
\text { control } \\
\text { studies }\end{array}$} & {$[42]$} & 1988 & PCC & 153 & 461 & USA & $1,162-2,948$ & Referent & $\begin{array}{l}\text { Matched analysis; } P \text { for } \\
\text { trend }=0.41\end{array}$ \\
\hline & & & & & & & $2,949-3,340$ & $0.65(0.33-1.26)$ & \\
\hline & & & & & & & $3,341-4,451$ & $0.76(0.41-1.43)$ & \\
\hline & {$[12]^{a}$} & 1992 & LCC & 458 & 1,197 & Sweden & $<2,500$ & $1.18(0.60-2.33)$ & $\begin{array}{l}\text { Adjusted for age and birth } \\
\text { date }\end{array}$ \\
\hline & & & & & & & $2,500-2,999$ & Referent & \\
\hline & & & & & & & $3,000-3,499$ & $1.29(0.90-1.91)$ & \\
\hline & & & & & & & $3,500-3,999$ & $1.47(1.00-2.18)$ & \\
\hline & & & & & & & $\geq 4,000$ & $1.23(0.80-2.00)$ & \\
\hline & [13] & 1996 & NCC & 550 & 1,478 & USA & $<2,500$ & $0.56(0.34-0.93)$ & Adjusted for age \\
\hline & & & & & & & $2,500-2,999$ & $0.68(0.47-0.99)$ & \\
\hline & & & & & & & $3,000-3,499$ & $0.71(0.50-0.99)$ & \\
\hline & & & & & & & $3,500-3,999$ & $0.85(0.59-1.22)$ & \\
\hline & & & & & & & $\geq 4,000$ & Referent & \\
\hline & {$[14]$} & 1996 & $\mathrm{PCC}$ & 922 & 1,194 & USA & $\begin{array}{l}\text { Age } 21-45 \\
\text { years: }\end{array}$ & & $\begin{array}{l}\text { Adjusted for age, } \\
\text { menopausal status, and } \\
\text { maternal smoking; } P \text { for } \\
\text { trend }=0.06 \text { among both } \\
\text { groups. The OR ( } 95 \% \mathrm{Cl}) \\
\text { for birth weight } \geq 4,000 \mathrm{~g} \\
\text { among patients with early- } \\
\text { onset breast cancer }(\leq 30 \\
\text { years old) was } 3.3(1.0- \\
11.0)\end{array}$ \\
\hline & & & & & & & $<2,500$ & $1.3(0.9-2.0)$ & \\
\hline & & & & & & & $2,500-2,999$ & Referent & \\
\hline & & & & & & & $3,000-3,499$ & $1.3(1.0-1.7)$ & \\
\hline & & & & & & & $3,500-3,999$ & $1.2(0.8-1.6)$ & \\
\hline & & & & & & & $\geq 4,000$ & $1.7(1.1-2.5)$ & \\
\hline & & & & & & & $\begin{array}{l}\text { Age } 50-64 \\
\text { years: }\end{array}$ & & \\
\hline & & & & & & & $<2,500$ & $0.9(0.5-1.7)$ & \\
\hline & & & & & & & $2,500-2,999$ & Referent & \\
\hline & & & & & & & $3,000-3,499$ & $1.1(0.7-1.7)$ & \\
\hline & & & & & & & $3,500-3,999$ & $0.8(0.4-1.3)$ & \\
\hline & & & & & & & $\geq 4,000$ & $0.6(0.3-1.1)$ & \\
\hline & [32] & 1997 & $\mathrm{NCC}$ & 1068 & 2,027 & Sweden & $<2,500$ & $0.80(0.50-1.26)$ & $\begin{array}{l}\text { Adjusted for maternal age, } \\
\text { socioeconomic status, } \\
\text { parity, and pre-eclampsia or } \\
\text { eclampsia, neonatal } \\
\text { jaundice, severe prematurity, } \\
\text { and twinship }\end{array}$ \\
\hline & & & & & & & $2,500-2,999$ & Referent & \\
\hline & & & & & & & $3,000-3,499$ & $1.00(0.79-1.28)$ & \\
\hline & & & & & & & $3,500-3,999$ & $0.99(0.77-1.26)$ & \\
\hline
\end{tabular}


Studies assessing the association of birth weight and the risk for breast cancer

\begin{tabular}{|c|c|c|c|c|c|c|c|c|}
\hline & & & & & & $\geq 4,000$ & $1.04(0.77-1.41)$ & \\
\hline \multirow[t]{5}{*}{ [33] } & 1998 & PCC & 510 & 436 & USA & $<2,500$ & $1.2(0.7-2.1)$ & Crude ORs \\
\hline & & & & & & $2,500-2,999$ & Referent & \\
\hline & & & & & & $3,000-3,499$ & $1.0(0.7-1.5)$ & \\
\hline & & & & & & $3,500-3,999$ & $1.0(0.7-1.5)$ & \\
\hline & & & & & & $\geq 4,000$ & $1.3(0.7-2.3)$ & \\
\hline \multirow[t]{5}{*}{ [15] } & 2000 & LCC & 484 & 2,870 & USA & $<1,500$ & $1.59(0.61-4.11)$ & Crude ORs \\
\hline & & & & & & $1,500-2,499$ & $1.33(0.94-1.90)$ & \\
\hline & & & & & & $2,500-3,499$ & Referent & \\
\hline & & & & & & $3,500-4,499$ & $1.08(0.87-1.34)$ & \\
\hline & & & & & & $\geq 4,500$ & $3.29(1.37-7.92)$ & \\
\hline \multirow[t]{5}{*}{ [34] } & 2001 & LTCC & 87 & 87 & Sweden & $<1,999$ & Referent & $\begin{array}{l}\text { Matched analysis by } \\
\text { conditional logistic } \\
\text { regression }\end{array}$ \\
\hline & & & & & & $2,000-2,499$ & $1.6(0.6-4.0)$ & \\
\hline & & & & & & $2,599-2,999$ & $2.4(0.9-6.2)$ & \\
\hline & & & & & & $\geq 3,000$ & $1.6(0.4-5.6)$ & \\
\hline & & & & & & & $(P$ trend $=0.05)$ & \\
\hline \multirow[t]{3}{*}{ [43] } & 2001 & LCC & 319 & 768 & USA & $<2,500$ & $1.4(0.55-3.4)$ & $\begin{array}{l}\text { Crude ORs. Higher birth } \\
\text { weight }(\geq 3,500 \mathrm{~g}) \text { carried a } \\
\text { marginal significantly higher } \\
\text { risk for breast cancer (OR } \\
1.76[95 \% \mathrm{Cl} 0.90-3.35]) \\
\text { relative to lower birth weight } \\
(<3,500 \mathrm{~g})\end{array}$ \\
\hline & & & & & & $2,500-3,750$ & Referent & \\
\hline & & & & & & $\geq 3,750$ & $0.9(0.50-1.6)$ & \\
\hline \multirow[t]{5}{*}{ [16] } & 2001 & LTCC & 90 & 90 & Sweden & $\leq 2,000$ & Referent & $\begin{array}{l}\text { Crude ORs. Study subjects } \\
\text { were women with opposite- } \\
\text { sexed pair twins }\end{array}$ \\
\hline & & & & & & $2,001-2,500$ & $3.2(0.8-12.6)$ & \\
\hline & & & & & & $2,501-3,000$ & $3.5(1-13)$ & \\
\hline & & & & & & $3,001-3,500$ & $5.8(1.3-25.7)$ & \\
\hline & & & & & & $\geq 3,501$ & $12.1(1.1-138.8)$ & \\
\hline \multirow[t]{6}{*}{ [35] } & 2002 & PCC & 2,088 & 2,187 & USA & $<2,500$ & $1.10(0.90-1.35)$ & $\begin{array}{l}\text { Adjusted for age and } \\
\text { residential regions (states) }\end{array}$ \\
\hline & & & & & & $2,500-2,999$ & $0.90(0.70-1.10)$ & \\
\hline & & & & & & $3,000-3,499$ & Referent & \\
\hline & & & & & & $3,500-3,999$ & $1.07(0.90-1.30)$ & \\
\hline & & & & & & $4,000-4,499$ & $0.89(0.70-1.14)$ & \\
\hline & & & & & & $\geq 4,500$ & $1.18(0.90-1.51)$ & \\
\hline [44] & 2002 & PCC & 288 & 350 & China & $<2,500$ & $0.9(0.4-2.0)$ & $\begin{array}{l}\text { Adjusted for age income, } \\
\text { family history of breast } \\
\text { cancer in first-degree } \\
\text { relative, history of } \\
\text { fibroadenoma, age at } \\
\text { menarche, parity, and age at } \\
\text { first live birth. }\end{array}$ \\
\hline
\end{tabular}


Table 2 (Continued)

Studies assessing the association of birth weight and the risk for breast cancer

\begin{tabular}{|c|c|c|c|c|c|c|c|c|}
\hline & & & & & & $2,500-2,999$ & Referent & \\
\hline & & & & & & $3,000-3,499$ & $1.1(0.8-1.6)$ & \\
\hline & & & & & & $3,500-3,999$ & $0.8(0.4-1.4)$ & \\
\hline & & & & & & $\geq 4,000$ & $0.7(0.4-1.4)$ & \\
\hline [17] & 2002 & LCC & 373 & 1,150 & USA & $<3,090$ & Referent & $\begin{array}{l}\text { Adjusted for parity and age } \\
\text { at first birth. } P \text { for trend }= \\
0.02\end{array}$ \\
\hline & & & & & & $3,090-3,410$ & $1.1(0.8-1.5)$ & \\
\hline & & & & & & $3,420-3,720$ & $1.2(0.9-1.6)$ & \\
\hline & & & & & & $\geq 3,630$ & $1.4(1.1-1.9)$ & \\
\hline [18] & 2003 & LCC & 881 & 3,423 & Denmark & $<2,500$ & $1.66(1.00-2.51)$ & $\begin{array}{l}\text { Adjusted for mother's marital } \\
\text { status, maternal age, and } \\
\text { birth order }\end{array}$ \\
\hline & & & & & & $2,500-2,999$ & $0.83(0.60-1.10)$ & \\
\hline & & & & & & $3,000-3,499$ & Referent & \\
\hline & & & & & & $3,500-3,999$ & $0.98(0.80-1.17)$ & \\
\hline & & & & & & $\geq 4,000$ & $1.25(1.00-1.55)$ & \\
\hline [19] & 2004 & NCC & 89 & 238 & Sweden & $100 \mathrm{~g}$ increase & $1.06(1.00-1.12)$ & $\begin{array}{l}\text { Adjusted for gestational age, } \\
\text { birth year, and maternal } \\
\text { hypertension/proteinuria }\end{array}$ \\
\hline [45] & 2004 & LCC & 2471 & 9801 & USA & $<1,500$ & $0.64(0.40-1.11)$ & $\begin{array}{l}\text { Adjusted for age and } \\
\text { maternal age at first birth }\end{array}$ \\
\hline & & & & & & $1,500-1,999$ & $1.05(0.70-1.68)$ & \\
\hline & & & & & & $2,000-2,499$ & $1.02(0.80-1.31)$ & \\
\hline & & & & & & $2,500-3,499$ & Referent & \\
\hline & & & & & & $3,500-3,999$ & $0.97(0.90-1.08)$ & \\
\hline & & & & & & $4,000-4,499$ & $0.93(0.80-1.11)$ & \\
\hline & & & & & & $\geq 4,500$ & $0.69(0.40-1.09)$ & \\
\hline [36] & 2004 & PCC & 196 & 167 & USA & All subjects: & & $\begin{array}{l}\text { Adjusted for age, race and } \\
\text { sampling fractions, body } \\
\text { mass index, household } \\
\text { income, and maternal age. } \\
\text { Tertiles are race specific } \\
\text { with cutpoints derived from } \\
\text { controls. White women: } \\
<3,062,3,062-3,458 \text {, } \\
>3,458 \text { g; black women: } \\
<3,146,3,146-3,488 \text {, } \\
>3,488 \text { g. Restricted data } \\
\text { using birth weight measured } \\
\text { in pounds and ounces and } \\
\text { participant delivered in a } \\
\text { medical facility by a } \\
\text { physician }\end{array}$ \\
\hline & & & & & & Lower tertile & $1.0(0.6-1.7)$ & \\
\hline & & & & & & Central tertile & Referent & \\
\hline & & & & & & Upper tertile & $0.7(0.4-1.2)$ & \\
\hline & & & & & & White, restricted & & \\
\hline & & & & & & data: & & \\
\hline & & & & & & Lower tertile & $1.1(0.5-2.4)$ & \\
\hline
\end{tabular}


Studies assessing the association of birth weight and the risk for breast cancer

\begin{tabular}{|c|c|c|c|c|c|c|c|c|c|}
\hline & & & & & & & Central tertile & Referent & \\
\hline & & & & & & & Upper tertile & $1.4(0.6-2.0)$ & \\
\hline & [20] & 2006 & PCC & 2,386 & 2,502 & Poland & $<2,500$ & Referent & $\begin{array}{l}\text { Adjusted for: age, } \\
\text { education, age at menarche, } \\
\text { menopausal status and age } \\
\text { at menopause, age at first } \\
\text { full-term pregnancy, number } \\
\text { of full-term pregnancies, } \\
\text { family history of breast } \\
\text { cancer among first-degree } \\
\text { relatives, mammography } \\
\text { screening, and current body } \\
\text { mass index. Lower birth } \\
\text { weight }(<2,500 \mathrm{~g}) \text { carries } \\
\text { greater risk than birth weight } \\
\text { of } 2,500-4,000 \mathrm{~g} \text { among } \\
\text { women under } 45 \text { years old }\end{array}$ \\
\hline & & & & & & & $2,500-4,000$ & $1.22(0.92-1.62)$ & \\
\hline & & & & & & & $>4,000$ & $1.54(1.08-2.19)$ & \\
\hline & & & & & & & & $(p$-trend $=0.01)$ & \\
\hline & [37] & 2006 & PCC & 1,166 & 2,105 & USA & $<2,495$ & $1.19(0.85-1.66)$ & $\begin{array}{l}\text { Adjusted for age (years), } \\
\text { education (years), race, } \\
\text { body mass index, history of } \\
\text { breast benign disease, } \\
\text { family history of breast } \\
\text { cancer, lactation (months), } \\
\text { age at menarche (years), } \\
\text { age at first full-term } \\
\text { pregnancy (years), age at } \\
\text { menopause (years), parity }\end{array}$ \\
\hline & & & & & & & $2,495-3,130$ & Referent & \\
\hline & & & & & & & $3,131-3,855$ & $0.97(0.75-1.25)$ & \\
\hline & & & & & & & $>3,855$ & $1.03(0.74-1.44)$ & \\
\hline $\begin{array}{l}\text { Cohort } \\
\text { studies }\end{array}$ & [21] & 1999 & LCohort & 57 & 152,590 & Sweden & $<2,500$ & Referent & $\begin{array}{l}\text { Standardization for sex, age, } \\
\text { and age-specific incidence } \\
\text { rate }\end{array}$ \\
\hline & & & & & & & $2,500-3,999$ & $1.3(0.6-2.4)$ & \\
\hline & & & & & & & $4,000-4,499$ & $1.2(0.0-6.7)$ & \\
\hline & & & & & & & $\geq 4,500$ & $1.3(0.7-2.3)$ & \\
\hline & [22] & 2000 & Cohort & 37 & 2,221 & UK & All ages & & $\begin{array}{l}\text { Adjusted for age. } P \text { for trend } \\
=0.03 \text { among } \\
\text { premenopausal women }\end{array}$ \\
\hline & & & & & & & $<3,000$ & Referent & \\
\hline & & & & & & & $3,000-3,499$ & $1.05(0.41-2.71)$ & \\
\hline & & & & & & & $3,500-3,999$ & $1.76(0.72-4.33)$ & \\
\hline & & & & & & & $\geq 4,000$ & $2.02(0.59-6.90)$ & \\
\hline & & & & & & & $\begin{array}{l}\text { Premenopausal } \\
\text { ages }\end{array}$ & & \\
\hline & & & & & & & $<3,000$ & Referent & \\
\hline & & & & & & & $3,000-3,499$ & $1.99(0.40-9.86)$ & \\
\hline & & & & & & & $3,500-3,999$ & $3.26(0.69-15.36)$ & \\
\hline & & & & & & & $\geq 4,000$ & $5.65(0.95-33.84)$ & \\
\hline & [38] & 2001 & LCohort & 177 & 3,447 & Sweden & $\leq 2,000$ & Referent & Crude hazard ratios \\
\hline
\end{tabular}


Studies assessing the association of birth weight and the risk for breast cancer

\begin{tabular}{|c|c|c|c|c|c|c|c|c|}
\hline & & & & & & $2,001-2,500$ & $1.4(0.6-3.4)$ & \\
\hline & & & & & & $2,501-3,000$ & $1.9(0.8-4.3)$ & \\
\hline & & & & & & $3,001-3,500$ & $1.5(0.6-3.5)$ & \\
\hline & & & & & & $\geq 3,501$ & $1.9(0.7-5.0)$ & \\
\hline \multirow[t]{5}{*}{ [39] } & 2001 & Cohort & 62 & 1260 & Sweden & $\leq 3,000$ & Referent & $\begin{array}{l}\text { Singleton only; adjusted for } \\
\text { gestational age and cohort } \\
\text { membership }\end{array}$ \\
\hline & & & & & & $3,010-3,349$ & $1.16(0.47-2.87)$ & \\
\hline & & & & & & $3,350-3,590$ & $1.65(0.71-3.86)$ & \\
\hline & & & & & & $3,600-3,960$ & $1.58(0.67-3.72)$ & \\
\hline & & & & & & $\geq 4,000$ & $1.57(0.67-3.64)$ & \\
\hline \multirow[t]{4}{*}{ [23] } & 2003 & LCohort & 63 & 5,352 & Sweden & $<3,000$ & Referent & $\begin{array}{l}\text { Crude ORs; } P \text { for } \\
\text { trend }=0.01\end{array}$ \\
\hline & & & & & & $3,000-3,499$ & $1.46(0.60-3.43)$ & \\
\hline & & & & & & $3,500-3,999$ & $2.09(0.90-4.85)$ & \\
\hline & & & & & & $\geq 4,000$ & $2.78(1.10-7.15)$ & \\
\hline [24] & 2003 & LCohort & 2,334 & 106,504 & Denmark & $1,000 \mathrm{~g}$ increase & $9(0.02-17) \%$ & $\begin{array}{l}\text { Adjusted for age and } \\
\text { calendar period. Additional } \\
\text { adjustment for parity and } \\
\text { age at first birth did not } \\
\text { indicate confounding }\end{array}$ \\
\hline \multirow[t]{3}{*}{ [25] } & 2003 & LCohort & 39 & 1483 & Sweden & $500-1,999$ & $1.14(0.70-1.85)$ & $\begin{array}{l}\text { Standardized incidence ratio } \\
\text { (expected/observed) }\end{array}$ \\
\hline & & & & & & $2,000-2,999$ & $0.71(0.40-1.15)$ & \\
\hline & & & & & & $\geq 3,000$ & $2.55(1.03-5.25)$ & \\
\hline \multirow[t]{6}{*}[26]{$^{\mathrm{a}}$} & 2004 & LCohort & 2,074 & 91,601 & Denmark & $\begin{array}{l}\text { Median of each } \\
\text { quintile }\end{array}$ & & $\begin{array}{l}\text { Adjusted for age and } \\
\text { calendar period. No change } \\
\text { in estimates when } \\
\text { additionally adjusted for } \\
\text { parity and age at first birth }\end{array}$ \\
\hline & & & & & & 2.5 & Referent & \\
\hline & & & & & & 3.0 & $0.98(0.85-1.13)$ & \\
\hline & & & & & & 3.4 & $1.06(0.93-1.20)$ & \\
\hline & & & & & & 3.6 & $1.05(0.87-1.27)$ & \\
\hline & & & & & & 4.0 & $1.17(1.02-1.33)$ & \\
\hline \multirow[t]{4}{*}{ [27] } & 2004 & Cohort & 59 & 2,176 & UK & $<3,000$ & Referent & $\begin{array}{l}\text { Adjusted for age; } P \text { for trend } \\
=0.03\end{array}$ \\
\hline & & & & & & $3,000-3,499$ & $1.37(0.34-5.47)$ & \\
\hline & & & & & & $3,500-3,999$ & $2.18(0.58-8.21)$ & \\
\hline & & & & & & $\geq 4,000$ & $5.03(1.13-22.47)$ & \\
\hline \multirow[t]{5}{*}{ [28] } & 2005 & LCohort & 311 & 16,011 & USA & $<3,040$ & Referent & Adjusted for year of birth \\
\hline & & & & & & $3,040-3,310$ & $1.4(1.0-2.1)$ & \\
\hline & & & & & & $3,320-3,550$ & $1.0(0.6-1.5)$ & \\
\hline & & & & & & $3,560-3,830$ & $1.3(0.9-1.9)$ & \\
\hline & & & & & & $\geq 3,840$ & $1.5(1.0-2.2)$ & \\
\hline$[29]^{a}$ & 2005 & LCohort & 367 & 5,346 & Sweden & $<50$ years & & \\
\hline
\end{tabular}


Studies assessing the association of birth weight and the risk for breast cancer

\begin{tabular}{|c|c|c|c|c|c|c|c|c|}
\hline & & & & & & $<3,000$ & Referent & \\
\hline & & & & & & $3,000-3,499$ & $1.81(0.77-4.26)$ & \\
\hline & & & & & & $3,500-3,999$ & $2.66(1.09-6.46)$ & \\
\hline & & & & & & $\geq 4,000$ & $4.00(1.49-10.72)$ & \\
\hline & & & & & & $\geq 50$ years & & \\
\hline & & & & & & $<3,000$ & Referent & \\
\hline & & & & & & $3,000-3,499$ & $0.86(0.62-1.19)$ & \\
\hline & & & & & & $3,500-3,999$ & $1.06(1.20-3.34)$ & \\
\hline & & & & & & $\geq 4,000$ & $0.91(0.57-1.46)$ & \\
\hline \multirow[t]{3}{*}{ [40] } & 2006 & Cohort & 97 & 5,847 & USA & $<3,000$ & $0.98(0.61-1.60)$ & Adjusted for age \\
\hline & & & & & & $3,000-3,499$ & Referent & \\
\hline & & & & & & $\geq 3,500$ & $1.09(0.66-1.80)$ & \\
\hline \multirow[t]{10}{*}{ [30] } & 2006 & Cohort & 3,140 & 91,601 & USA & Premenopause & & $\begin{array}{l}\text { Adjusted for age: } P \text { for trend } \\
=0.019\end{array}$ \\
\hline & & & & & & $<2,495$ & $0.69(0.50-0.94)$ & \\
\hline & & & & & & $2,495-3,130$ & $0.79(0.64-0.97)$ & \\
\hline & & & & & & $3,131-3,810$ & $0.76(0.63-0.93)$ & \\
\hline & & & & & & $>3,810$ & Referent & \\
\hline & & & & & & Postmenopause: & & $\begin{array}{l}\text { Adjusted for age: } P \text { for trend } \\
=0.99\end{array}$ \\
\hline & & & & & & $<2,495$ & $1.04(0.88-1.23)$ & \\
\hline & & & & & & $2,495-3,130$ & $1.00(0.87-1.14)$ & \\
\hline & & & & & & $3,131-3,855$ & $1.05(0.93-1.20)$ & \\
\hline & & & & & & $>3,855$ & Referent & \\
\hline \multirow[t]{3}{*}{ [31] } & 2006 & Cohort & 209 & 1,024 & USA & $<2,500$ & $0.9(0.5-1.6)$ & $\begin{array}{l}\text { Hazard ratio; adjusted for } \\
\text { age at diagnosis, diagnosis } \\
\text { year, stage at diagnosis, and } \\
\text { birth order, with exception of } \\
\text { birth order, which is } \\
\text { adjusted for maternal age }\end{array}$ \\
\hline & & & & & & $2,500-3,999$ & Referent & \\
\hline & & & & & & $\geq 4,000$ & $\begin{array}{l}1.8(1.0-3.1) \\
(P \text { trend }=0.1)\end{array}$ & \\
\hline \multirow[t]{3}{*}{ [41] } & 2007 & Cohort & 657 & 38,566 & Sweden & $<2,500$ & $0.65(0.43-0.99)$ & $\begin{array}{l}\text { Adjusted for adult body } \\
\text { mass index }\end{array}$ \\
\hline & & & & & & $2,500-3,000$ & $1.04(0.86-1.25)$ & \\
\hline & & & & & & $>3,000$ & Referent & \\
\hline
\end{tabular}

Cohort, cohort study; LCC, case-control study with linkage with population and cancer registry data; LCohort, cohort study with linkage with population and cancer registry data; LTCCS, twin case-control study by using linkage with birth and cancer registry data; NCC, nested casecontrol study in cohort; PCC, population-based case-control study. ${ }^{a}$ The numbers of cases and controls were not shown in the original article. 
Breast Cancer Research Vol 10 No 1 Park et al.

Table 3

Studies assessing the association of birth order and the risk of breast cancer

\begin{tabular}{|c|c|c|c|c|c|c|c|c|c|}
\hline $\begin{array}{l}\text { Type of } \\
\text { study }\end{array}$ & Ref. & Year & Design & Cases & $\begin{array}{l}\text { Controls } \\
\text { (or cohort) }\end{array}$ & $\begin{array}{l}\text { Country/ } \\
\text { place of study }\end{array}$ & $\begin{array}{l}\text { Birth } \\
\text { order }\end{array}$ & OR $(95 \% \mathrm{Cl})$ & Comments \\
\hline \multirow[t]{30}{*}{$\begin{array}{l}\text { Case- } \\
\text { control } \\
\text { studies }\end{array}$} & {$[51]$} & 1967 & LCC-D & 229 & 229 & USA & 1 & - & $\begin{array}{l}\text { The authors measured the } \\
\text { mean value of birth weight } \\
\text { instead of providing ORs ( } 95 \% \\
\text { Cls). The mean difference } \\
\text { between cases and matched } \\
\text { controls was not significant }(P \\
>0.2) \text {. They provided the } \\
\text { frequency of each case and } \\
\text { control in the tables and we } \\
\text { calculated crude ORs }\end{array}$ \\
\hline & & & & & & & 2 & & \\
\hline & & & & & & & 3 & & \\
\hline & & & & & & & 4 & & \\
\hline & & & & & & & 5 & & \\
\hline & & & & & & & 6 & & \\
\hline & & & & & & & $\geq 7$ & & \\
\hline & {$[50]^{a}$} & 1980 & MCC & 4339 & 12,760 & $\begin{array}{l}\text { USA, Japan, } \\
\text { Slovenia, } \\
\text { Athens, Taipei }\end{array}$ & 1 & Referent & $\begin{array}{l}\text { The risks (point estimates) only } \\
\text { by birth order were shown in } \\
\text { the figure in the original article. }\end{array}$ \\
\hline & & & & & & & 2 & 0.93 & \\
\hline & & & & & & & 3 & 1.08 & \\
\hline & & & & & & & 4 & 0.99 & \\
\hline & & & & & & & 5 & 1.05 & \\
\hline & & & & & & & 6 & 1.07 & \\
\hline & & & & & & & 7 & 1.18 & \\
\hline & & & & & & & $\geq 8$ & 1.02 & \\
\hline & [42] & 1988 & PCC & 153 & 461 & USA & 1 & Referent & $P$ for trend $=0.16$ \\
\hline & & & & & & & 2 & $0.92(0.55-1.54)$ & \\
\hline & & & & & & & 3 & $0.98(0.58-1.72)$ & \\
\hline & & & & & & & 4 & $0.69(0.36-1.32)$ & \\
\hline & & & & & & & $\geq 5$ & $1.03(0.60-1.79)$ & \\
\hline & {$[46]$} & 1991 & MCC & 927 & 2,616 & $\begin{array}{l}\text { USA/Wales/ } \\
\text { Japan }\end{array}$ & All ages & & $\begin{array}{l}\text { Adjusted for age, study center, } \\
\text { parity, age at first birth, age at } \\
\text { menarche, height, body mass } \\
\text { index, maternal age at birth, and } \\
\text { menopausal status }\end{array}$ \\
\hline & & & & & & & 1 & Referent & \\
\hline & & & & & & & 2 & $0.91(0.73-1.02)$ & \\
\hline & & & & & & & 3 & $1.11(0.87-1.27)$ & \\
\hline & & & & & & & $\geq 4$ & $1.09(0.81-1.18)$ & \\
\hline & & & & & & & $\begin{array}{l}\text { Premenopa } \\
\text { usal }\end{array}$ & & \\
\hline & & & & & & & 1 & Referent & \\
\hline & & & & & & & $\geq 2$ & $0.76(0.60-0.96)$ & \\
\hline & {$[12]$} & 1992 & LCC & 458 & 1,197 & Sweden & 1 & Referent & Adjusted for age and birth date \\
\hline & & & & & & & $\geq 2$ & $1.00(0.76-1.32)$ & \\
\hline
\end{tabular}


Studies assessing the association of birth order and the risk of breast cancer

\begin{tabular}{|c|c|c|c|c|c|c|c|c|}
\hline [47] & 1994 & PCC & 2,414 & 9,138 & USA & 1 & Referent & $\begin{array}{l}\text { Adjusted for age at first birth } \\
\text { and number of children }\end{array}$ \\
\hline & & & & & & 2 & $0.90(0.78-1.03)$ & \\
\hline & & & & & & 3 & $0.98(0.84-1.14)$ & \\
\hline & & & & & & 4 & $0.86(0.73-1.02)$ & \\
\hline & & & & & & 5 & $0.93(0.78-1.11)$ & \\
\hline & & & & & & 6 & $1.02(0.84-1.23)$ & \\
\hline & & & & & & 7 & $0.91(0.73-1.14)$ & \\
\hline & & & & & & $\geq 8$ & $0.88(0.75-1.04)$ & \\
\hline [14] & 1996 & PCC & 1,129 & 1,393 & USA & 1 & Referent & $\begin{array}{l}\text { Adjusted for age, menopausal } \\
\text { status, and maternal smoking; } \\
P \text { for trend }=0.06 \text { among both } \\
\text { groups }\end{array}$ \\
\hline & & & & & & 2 & $1.0(0.7-1.4)$ & \\
\hline & & & & & & $\geq 3$ & $0.8(0.6-1.1)$ & \\
\hline [32] & 1997 & NCC & 1,068 & 2,727 & Sweden & 1 & Referent & $\begin{array}{l}\text { Adjusted for maternal age, } \\
\text { socioeconomic status, parity, } \\
\text { and preeclampsia or eclampsia, } \\
\text { neonatal jaundice, severe } \\
\text { prematurity, and twinship }\end{array}$ \\
\hline & & & & & & 2 & $1.01(0.83-1.22)$ & \\
\hline & & & & & & $\geq 3$ & $1.01(0.81-1.26)$ & \\
\hline [15] & 2000 & LCC & 481 & 2,863 & USA & 1 & $1.07(0.84-1.35)$ & Crude ORs \\
\hline & & & & & & $2-3$ & Referent & \\
\hline & & & & & & $4-5$ & $1.06(0.81-1.38)$ & \\
\hline & & & & & & $\geq 6$ & $1.50(1.06-2.13)$ & \\
\hline [35] & 2002 & PCC & 1,555 & 1,539 & USA & 1 & Referent & $\begin{array}{l}\text { Adjusted for age and residential } \\
\text { regions (states) }\end{array}$ \\
\hline & & & & & & 2 & $1.07(0.88-1.30)$ & \\
\hline & & & & & & 3 & $1.07(0.85-1.35)$ & \\
\hline & & & & & & 4 & $1.01(0.77-1.31)$ & \\
\hline & & & & & & 5 & $0.66(0.48-0.92)$ & \\
\hline & & & & & & $\geq 6$ & $0.81(0.62-1.08)$ & \\
\hline [18] & 2003 & LCC & 881 & 3,423 & Denmark & 1 & Referent & $\begin{array}{l}\text { Adjusted for mother's marital } \\
\text { status, maternal age, and birth } \\
\text { order }\end{array}$ \\
\hline & & & & & & $\geq 2$ & $1.01(0.83-1.12)$ & \\
\hline [36] & 2004 & PCC & 854 & 785 & USA & All subjects & & $\begin{array}{l}\text { Adjusted for age, race and } \\
\text { sampling fractions, body mass } \\
\text { index, hosehold income, } \\
\text { maternal age }\end{array}$ \\
\hline & & & & & & 1 & Referent & \\
\hline & & & & & & $2-4$ & $0.9(0.7-1.1)$ & \\
\hline & & & & & & $\geq 5$ & $1.0(0.8-1.3)$ & \\
\hline & & & & & & $\begin{array}{l}\text { Born } \geq \\
1948\end{array}$ & & \\
\hline & & & & & & 1 & Referent & \\
\hline
\end{tabular}


Breast Cancer Research Vol 10 No 1 Park et al.

Table 3 (Continued)

Studies assessing the association of birth order and the risk of breast cancer

\begin{tabular}{|c|c|c|c|c|c|c|c|c|c|}
\hline & & & & & & & $2-4$ & $0.9(0.6-1.4)$ & \\
\hline & & & & & & & $\geq 5$ & $0.6(0.3-1.3)$ & \\
\hline & \multirow[t]{2}{*}[48]{$^{\mathrm{a}}$} & 2005 & MCC & 24 & 34 & Nigeria & $\leq 3$ & Referent & Crude ORs \\
\hline & & & & & & & $\geq 4$ & $1.50(0.25-8.98)$ & \\
\hline & \multirow[t]{5}{*}{ [20] } & \multirow[t]{5}{*}{2005} & \multirow[t]{5}{*}{ PCC } & \multirow[t]{5}{*}{1642} & \multirow[t]{5}{*}{1,713} & \multirow[t]{5}{*}{ Poland } & 1 & Referent & \multirow[t]{5}{*}{$\begin{array}{l}\text { Adjusted for age, education, } \\
\text { age at menarche, menopausal } \\
\text { status and age at menopause, } \\
\text { age at first full-term pregnancy, } \\
\text { number of full-term } \\
\text { pregnancies, family history of } \\
\text { breast cancer among first- } \\
\text { degree relatives, } \\
\text { mammography screening, and } \\
\text { current body mass index }\end{array}$} \\
\hline & & & & & & & 2 & $1.07(0.91-1.24)$ & \\
\hline & & & & & & & $3-5$ & $0.99(0.85-1.15)$ & \\
\hline & & & & & & & $\geq 6$ & $0.81(0.61-1.06)$ & \\
\hline & & & & & & & & $P$ for trend $=0.81$ & \\
\hline & \multirow[t]{2}{*}{ [37] } & \multirow[t]{2}{*}{2006} & \multirow[t]{2}{*}{ PCC } & \multirow[t]{2}{*}{1,166} & \multirow[t]{2}{*}{2,105} & \multirow[t]{2}{*}{ USA } & 1 & Referent & $\begin{array}{l}\text { Adjusted for age (years), } \\
\text { education (years), race, body } \\
\text { mass index, history of breast } \\
\text { benign disease, family history of } \\
\text { breast cancer, lactation } \\
\text { (months), age at menarche } \\
\text { (years), age at first full-term } \\
\text { pregnancy (years), age at } \\
\text { menopause (years), parity }\end{array}$ \\
\hline & & & & & & & $\geq 2$ & $1.27(0.88-1.85)$ & \\
\hline \multirow[t]{5}{*}{$\begin{array}{l}\text { Cohort } \\
\text { studies }\end{array}$} & \multirow[t]{4}{*}{ [31] } & \multirow[t]{4}{*}{2006} & \multirow[t]{4}{*}{ Cohort } & \multirow[t]{4}{*}{209} & \multirow[t]{4}{*}{1,024} & \multirow[t]{4}{*}{ USA } & 1 & Referent & $\begin{array}{l}\text { Hazard ratio for breast cancer } \\
\text { mortality: adjusted for age at } \\
\text { diagnosis, diagnosis year, } \\
\text { stage at diagnosis, and birth } \\
\text { order, with exception of birth } \\
\text { order, which is adjusted for } \\
\text { maternal age }\end{array}$ \\
\hline & & & & & & & 2 & $0.2(0.2-0.3)$ & \\
\hline & & & & & & & $\geq 3$ & $0.2(0.2-0.3)$ & \\
\hline & & & & & & & & $P$ for trend $<0.01$ & \\
\hline & {$[49]^{a}$} & 2001 & Cohort & - & - & Sweden & $\begin{array}{l}\text { Continuous } \\
\text { scale }\end{array}$ & $1.05(1.01-1.10)$ & \\
\hline
\end{tabular}

aWe did not include these studies in the meta-analysis because they employed different categories or a continuous scale, or they did not provide the numbers of cases and controls in the original article. Cohort, cohort study; LCC, case-control study with linkage with population and cancer registry data; LCC-D, case-control study with linkage with population and cancer death certification data; MCC, multicenter case-control study; NCC, nested case-control study in cohort; PCC, population-based case-control study. 
Table 4

Studies assessing the association of maternal age with risk for breast cancer

\begin{tabular}{|c|c|c|c|c|c|c|c|c|c|}
\hline & Ref. & Year & Design & Cases & $\begin{array}{l}\text { Controls } \\
\text { (or cohort) }\end{array}$ & $\begin{array}{l}\text { Country/ } \\
\text { place of study }\end{array}$ & $\begin{array}{l}\text { Maternal } \\
\text { age (years) }\end{array}$ & OR $(95 \% \mathrm{Cl})$ & Comments \\
\hline \multirow[t]{27}{*}{$\begin{array}{l}\text { Case- } \\
\text { control } \\
\text { studies }\end{array}$} & [51] & 1967 & LCC-D & 229 & 229 & USA & $\leq 19$ & & $\begin{array}{l}\text { Mean maternal age among } \\
\text { cases was higher than that } \\
\text { among controls }(P<0.005) \text {. } \\
\text { The frequency of each case and } \\
\text { control were shown in the tables } \\
\text { provided and we calculated } \\
\text { crude ORs }\end{array}$ \\
\hline & & & & & & & $20-24$ & & \\
\hline & & & & & & & $25-29$ & & \\
\hline & & & & & & & $30-34$ & & \\
\hline & & & & & & & $35-39$ & & \\
\hline & & & & & & & $\geq 40$ & & \\
\hline & {$[61]^{\mathrm{a}}$} & 1974 & PCC & 308 & 308 & USA & & & $\begin{array}{l}\text { Matched analysis; the mean } \\
\text { maternal age was } 27.3 \text { years } \\
\text { among cases and } 26.3 \text { years } \\
\text { among controls }(P<0.01)\end{array}$ \\
\hline & {$[50]^{\mathrm{b}}$} & 1980 & MCC & 4339 & 12760 & $\begin{array}{l}\text { USA, Japan, } \\
\text { Slovenia, } \\
\text { Athens, Taipei }\end{array}$ & $\leq 19$ & Referent & $\begin{array}{l}\text { Authors showed point estimates } \\
\text { of ORs without } 95 \% \text { Cls. The } \\
\text { frequencies for each case and } \\
\text { control were given in the tables } \\
\text { provided and we calculated } \\
\text { crude ORs }\end{array}$ \\
\hline & & & & & & & $20-24$ & 1.05 & \\
\hline & & & & & & & $25-29$ & 1.22 & \\
\hline & & & & & & & $30-34$ & 1.19 & \\
\hline & & & & & & & $35-39$ & 1.31 & \\
\hline & & & & & & & $\geq 40$ & 1.18 & \\
\hline & {$[53]^{a}$} & 1984 & MCC & 1,176 & 1,176 & England & $\leq 20$ & Referent & $\begin{array}{l}\text { Adjusted for age, social class, } \\
\text { family history of breast cancer, } \\
\text { age at first-term birth, past } \\
\text { history of benign breast disease, } \\
\text { age at menarche, menopausal } \\
\text { status, cigarette smoking, and } \\
\text { oral contraceptive use }\end{array}$ \\
\hline & & & & & & & $21-25$ & $1.41(0.92-2.18)$ & \\
\hline & & & & & & & $26-30$ & $1.19(0.78-1.81)$ & \\
\hline & & & & & & & $31-35$ & $1.29(0.83-1.98)$ & \\
\hline & & & & & & & $\geq 36$ & $1.19(0.68-1.67)$ & \\
\hline & {$[42]^{a}$} & 1988 & PCC & 153 & 461 & USA & All women & & Matched analysis \\
\hline & & & & & & & $15-22$ & $1.18(0.71-1.97)$ & \\
\hline & & & & & & & $23-26$ & Referent & \\
\hline & & & & & & & $27-30$ & $1.22(0.71-2.10)$ & \\
\hline & & & & & & & $31-46$ & $1.66(0.99-2.78)$ & \\
\hline & & & & & & & & $\begin{array}{l}P \text { for trend }= \\
0.67\end{array}$ & \\
\hline & & & & & & & $\begin{array}{l}\text { Younger } \\
\text { women }\end{array}$ & & \\
\hline & & & & & & & $15-23$ & $1.39(0.65-2.95)$ & \\
\hline & & & & & & & $24-28$ & Referent & \\
\hline
\end{tabular}


Studies assessing the association of maternal age with risk for breast cancer

\begin{tabular}{|c|c|c|c|c|c|c|c|c|}
\hline & & & & & & $29-46$ & $2.21(1.02-4.80)$ & \\
\hline & & & & & & & $\begin{array}{l}P \text { for trend }= \\
0.08\end{array}$ & \\
\hline$[52]^{\mathrm{a}}$ & 1989 & PCC & 801 & 1,573 & USA & Continuous & $1.24(1.09-1.41)$ & Crude OR \\
\hline [54] & 1990 & PCC & 2,291 & 3,144 & USA & $\leq 19$ & Referent & $\begin{array}{l}\text { Adjusted for age and parity, age } \\
\text { at first pregnancy, total duration } \\
\text { of breast feeding, race, age at } \\
\text { menarche, menopausal status, } \\
\text { body mass index, family history } \\
\text { of breast cancer, and breast } \\
\text { biopsy }\end{array}$ \\
\hline & & & & & & $20-24$ & $0.95(0.77-1.16)$ & \\
\hline & & & & & & $25-29$ & $1.13(0.92-1.38)$ & \\
\hline & & & & & & $30-34$ & $1.16(0.93-1.45)$ & \\
\hline & & & & & & $35-39$ & $1.46(1.10-1.93)$ & \\
\hline & & & & & & $\geq 40$ & $1.20(0.79-1.83)$ & \\
\hline [55] & 1991 & PCC & 1761 & $\begin{array}{l}1,116,55 \\
3 \text { person- } \\
\text { years }\end{array}$ & USA & $\leq 19$ & Referent & Crude ORs \\
\hline & & & & & & $20-24$ & $1.02(0.82-1.46)$ & \\
\hline & & & & & & $25-29$ & $1.12(1.04-1.38)$ & \\
\hline & & & & & & $30-34$ & $1.16(0.93-1.44)$ & \\
\hline & & & & & & $35-39$ & $1.17(0.92-1.48)$ & \\
\hline & & & & & & $\geq 40$ & $1.08(0.80-1.46)$ & \\
\hline$[46]^{a}$ & 1991 & MCC & 927 & 2616 & $\begin{array}{l}\text { USA, Wales, } \\
\text { Japan }\end{array}$ & Each 5-yrs & $1.06(1.01-1.10)$ & $\begin{array}{l}\text { Adjusted for age, study center, } \\
\text { parity, age at first birth, age at } \\
\text { menarche, height, BMl, maternal } \\
\text { age at birth, and menopausal } \\
\text { status }\end{array}$ \\
\hline$[12]^{b}$ & 1992 & LCC & 458 & 1,197 & Sweden & $\begin{array}{l}\text { Each 5-year } \\
\text { band }\end{array}$ & $1.01(0.92-1.12)$ & $\begin{array}{l}\text { Adjusted for age and birth date. } \\
\text { The authors estimated breast } \\
\text { cancer risk according to each 5- } \\
\text { year band of maternal age. The } \\
\text { frequency of each case and } \\
\text { control were given in the tables } \\
\text { provided and we calculated } \\
\text { crude ORs }\end{array}$ \\
\hline [47] & 1994 & PCC & 2,412 & 9,138 & USA & $\leq 19$ & Referent & $\begin{array}{l}\text { Adjusted for age at first birth } \\
\text { and number of children }\end{array}$ \\
\hline & & & & & & $20-24$ & $1.05(0.85-1.30)$ & \\
\hline & & & & & & $25-29$ & $1.10(0.89-1.37)$ & \\
\hline & & & & & & $30-34$ & $1.10(0.88-1.37)$ & \\
\hline & & & & & & $35-39$ & $1.09(0.87-1.37)$ & \\
\hline & & & & & & $\geq 40$ & $0.99(0.76-1.28)$ & \\
\hline [14] & 1996 & PCC & 1,934 & 2,161 & USA & $\leq 24$ & Referent & $\begin{array}{l}\text { Adjusted for age, menopausal } \\
\text { status, and maternal smoking }\end{array}$ \\
\hline & & & & & & $25-29$ & $1.0(0.8-1.2)$ & \\
\hline & & & & & & $30-34$ & $0.9(0.6-1.1)$ & \\
\hline & & & & & & $\geq 35$ & $1.0(0.7-1.5)$ & \\
\hline
\end{tabular}




\section{Studies assessing the association of maternal age with risk for breast cancer}

\section{$[57$}

1997 PCC

$1,253 \quad 1,121$

USA

8] $1997 \mathrm{PC}$

$2,106 \quad 1,926$

USA

[32] $]^{a} 1997$ NCC

$1,067 \quad 2,725$

Sweden

[15] 2000 LCC

481

2863

USA

[35] 2002 PCC

1,55

1,539

USA

(n)

$[18]$

2003

$881 \quad 3,423$

3,423

Denmark

[36 $^{\mathrm{a}} 2004$ PCC

85

785
25-29

$\geq 30$

$\leq 18$ $\leq 19$

Referent
25-29

30-34

35-39

$\geq 40$

$\leq 19$
Adjusted for age, menopausal status, age at menarche, parity, age at first birth, body mass index, past history of benign breast disease, and recent alcohol intake

$0.84(0.62-1.14)$

$1.02(0.76-1.37)$

$0.93(0.68-1.28)$

$1.16(0.82-1.65)$

$0.92(0.62-1.37)$

Referent

Adjusted for age, study site, family history of breast cancer, breast biopsy, a combination variable including number of fullterm births and age at first fullterm pregnancy, age at menarche, menopausal status, body mass index, average lifetime alcohol consumption, and the number of mammograms

Adjusted for maternal age, socioeconomic status, parity, and pre-eclampsia or eclampsia, neonatal jaundice, severe prematurity, and twinship

$\begin{array}{ll}20-24 & 0.96(0.7-1.2) \\ 25-29 & 0.96(0.7-1.2) \\ 30-34 & 0.91(0.7-1.2) \\ \geq 35 & 0.93(0.7-1.3) \\ \begin{array}{l}\text { Each 5-year } \\ \text { band }\end{array} & 1.06(0.99-1.14)\end{array}$

Crude ORs

$\leq 19$

$1.19(0.83-1.72)$

Referent

$20-24$

$1.26(0.97-1.64)$

25-29

$1.38(1.04-1.84)$

30-34

$1.70(1.23-2.35)$

$\geq 35$

$1.02(0.75-1.39)$

$\leq 19$

$0.98(0.81-1.18)$

20-24

Referent

25-29

$1.15(0.93-1.42)$

$30-34$

$1.22(0.94-1.58)$

35-39

$1.27(0.90-1.69)$

$\geq 40$

$\leq 24$

Referent

Adjusted for mother's marital status, maternal age, and birth order

Adjusted for age and state
$1.08(0.88-1.32)$

$1.11(0.90-1.36)$

$1.8(0.9-3.4)$ 
Table 4 (Continued)

Studies assessing the association of maternal age with risk for breast cancer

\begin{tabular}{|c|c|c|c|c|c|c|c|c|c|}
\hline & & & & & & & $19-22$ & Referent & $\begin{array}{l}\text { Adjusted for age, race and } \\
\text { sampling fractions; tertiles are } \\
\text { race specific with cutpoints } \\
\text { derived from controls }\end{array}$ \\
\hline & & & & & & & $23-27$ & $3.0(1.8-5.0)$ & \\
\hline & & & & & & & $\geq 28$ & $2.5(1.6-4.0)$ & \\
\hline & \multirow[t]{4}{*}[56]{} & 2005 & MCC & 1,060 & 1,060 & Korea & $\leq 24$ & Referent & $\begin{array}{l}\text { Adjusted for age, family history } \\
\text { of breast cancer in first-or } \\
\text { second-degree relatives, } \\
\text { menopausal status, and lifetime } \\
\text { estrogen exposure duration }\end{array}$ \\
\hline & & & & & & & $25-29$ & $1.2(0.93-1.47)$ & \\
\hline & & & & & & & $30-34$ & $1.4(1.12-1.83)$ & \\
\hline & & & & & & & $\geq 35$ & $1.1(0.83-1.37)$ & \\
\hline & \multirow[t]{6}{*}[20]{} & 2006 & PCC & 1,642 & 1,713 & Poland & $\leq 19$ & Referent & $\begin{array}{l}\text { Adjusted for: age, education, } \\
\text { age at menarche, menopausal } \\
\text { status and age at menopause, } \\
\text { age at first full-term pregnancy, } \\
\text { number of full-term pregnancies, } \\
\text { family history of breast cancer } \\
\text { among first-degree relatives, } \\
\text { mammography screening, and } \\
\text { current body mass index }\end{array}$ \\
\hline & & & & & & & $20-24$ & $1.02(0.75-1.39)$ & \\
\hline & & & & & & & $25-29$ & $1.07(0.79-1.46)$ & \\
\hline & & & & & & & $35-39$ & $1.16(0.84-1.60)$ & \\
\hline & & & & & & & $\geq 35$ & $0.91(0.66-1.27)$ & \\
\hline & & & & & & & & $\begin{array}{l}P \text { for trend }= \\
0.76\end{array}$ & \\
\hline & \multirow[t]{3}{*}[37]{$^{a}$} & 2006 & PCC & 1,166 & 2,105 & USA & $\leq 24$ & Referent & $\begin{array}{l}\text { Adjusted for: age, education, } \\
\text { race, body mass index, history of } \\
\text { breast benign disease, family } \\
\text { history of breast cancer, } \\
\text { lactation, age at menarche, age } \\
\text { at first full-term pregnancy, age } \\
\text { at menopause, and parity }\end{array}$ \\
\hline & & & & & & & $25-35$ & $0.87(0.67-1.13)$ & \\
\hline & & & & & & & $>35$ & $0.87(0.59-1.27)$ & \\
\hline \multirow[t]{10}{*}{$\begin{array}{l}\text { Cohort } \\
\text { studies }\end{array}$} & \multirow[t]{4}{*}{ [59] } & 1995 & Cohort & 149 & 75,237 & USA & $\leq 24$ & Referent & $\begin{array}{l}\text { Adjusted for age, education, } \\
\text { menopausal status, parity, body } \\
\text { mass index, height, smoking, } \\
\text { and alcohol drinking }\end{array}$ \\
\hline & & & & & & & $25-29$ & $1.3(0.8-2.0)$ & \\
\hline & & & & & & & $30-34$ & $1.4(0.9-2.1)$ & \\
\hline & & & & & & & $\geq 35$ & $1.2(0.7-2.0)$ & \\
\hline & \multirow[t]{6}{*}[60]{} & 1995 & Cohort & 1,967 & 384,769 & Sweden & $\leq 19$ & Referent & $\begin{array}{l}\text { Breast cancer mortality; } \\
\text { adjusted for age }\end{array}$ \\
\hline & & & & & & & $20-24$ & $0.99(0.82-1.21)$ & \\
\hline & & & & & & & $25-29$ & $1.00(0.82-1.22)$ & \\
\hline & & & & & & & $30-34$ & $0.97(0.79-1.18)$ & \\
\hline & & & & & & & $35-39$ & $1.04(0.84-1.29)$ & \\
\hline & & & & & & & $40-44$ & $0.93(0.71-1.21)$ & \\
\hline
\end{tabular}


Studies assessing the association of maternal age with risk for breast cancer

\begin{tabular}{|c|c|c|c|c|c|c|c|c|}
\hline & & & & & & $\geq 45$ & $1.39(0.91-2.13)$ & \\
\hline$[49]^{a}$ & 2001 & Cohort & & & Sweden & $\begin{array}{l}\text { Continuous } \\
\text { scale }\end{array}$ & $1.07(0.91-1.27)$ & $\begin{array}{l}\text { Adjusted for spouse age, year of } \\
\text { diagnosis, and birth order }\end{array}$ \\
\hline$[38]^{\mathrm{a}}$ & 2001 & Cohort & 177 & 3,447 & Filand & $\begin{array}{l}\text { Continuous } \\
\text { scale }\end{array}$ & - & No association \\
\hline \multirow[t]{5}{*}{ [31] } & 2006 & Cohort & 249 & 1,024 & USA & $\leq 24$ & Referent & $\begin{array}{l}\text { Hazard ratio; adjusted for age at } \\
\text { diagnosis, diagnosis year, stage } \\
\text { at diagnosis, and birth order, } \\
\text { with exception of birth order, } \\
\text { which is adjusted for maternal } \\
\text { age }\end{array}$ \\
\hline & & & & & & $25-29$ & $1.2(0.9-1.7)$ & \\
\hline & & & & & & $30-34$ & $1.4(0.9-1.9)$ & \\
\hline & & & & & & $\geq 35$ & $1.7(1.1-2.8)$ & \\
\hline & & & & & & & $\begin{array}{l}P \text { for trend }= \\
0.03\end{array}$ & \\
\hline
\end{tabular}

aWe did not include these studies in the meta-analysis because they employed different categories or a continuous scale, or they did not provide the numbers of cases and controls in the original articlebWe included this study in the meta-analysis because we calculated the crude OR using the number of subjects represented the original article. Cohort, cohort study; LCC, case-control study with linkage with population and cancer registry data; LCC-D, case-control study with linkage with population and cancer death certification data; MCC, multicenter case-control study; NCC, nested case-control study in cohort; PCC, population-based case-control study. 
Breast Cancer Research Vol 10 No 1 Park et al.

Table 5

Table 5 Studies assessing the association of premature birth and the risk of breast cancer

\begin{tabular}{|c|c|c|c|c|c|c|c|c|c|}
\hline $\begin{array}{l}\text { Type of } \\
\text { study }\end{array}$ & Author & Year & Design & Cases & $\begin{array}{l}\text { Controls } \\
\text { (or cohort) }\end{array}$ & $\begin{array}{l}\text { Country/ } \\
\text { place of study }\end{array}$ & $\begin{array}{l}\text { Gestational } \\
\text { age (weeks) }\end{array}$ & OR (95\% Cl) & Comments \\
\hline \multirow{28}{*}{$\begin{array}{l}\text { Case- } \\
\text { control } \\
\text { studies }\end{array}$} & {$[42]^{a}$} & 1988 & $\mathrm{PCC}$ & 153 & 461 & USA & $25-32$ & $1.16(0.50-1.54)$ & Matched analysis \\
\hline & & & & & & & $33-40$ & Referent & \\
\hline & {$[13]^{b}$} & 1996 & $\mathrm{NCC}$ & 571 & 1,525 & USA & Categorical & & Adjusted for age \\
\hline & & & & & & & 40 & Referent & \\
\hline & & & & & & & $38-39$ & $0.76(0.44-1.32)$ & \\
\hline & & & & & & & $36-37$ & $0.96(0.59-1.56)$ & \\
\hline & & & & & & & Binomial & & \\
\hline & & & & & & & $\geq 37$ & Referent & \\
\hline & & & & & & & $\leq 36$ & $0.82(0.37-1.82)$ & \\
\hline & {$[14]$} & 1996 & PCC & 1123 & 1371 & USA & Nonpreterm & Referent & $\begin{array}{l}\text { Adjusted for age, } \\
\text { menopausal status, and } \\
\text { maternal smoking }\end{array}$ \\
\hline & & & & & & & Preterm & $1.1(0.5-2.1)$ & \\
\hline & {$[32] \mathrm{a}$} & 1997 & NCC & 1,010 & 2,625 & Sweden & $\geq 33$ & Referent & $\begin{array}{l}\text { Adjusted for maternal } \\
\text { age, matermal } \\
\text { socioeconomic status, } \\
\text { maternal parity, } \\
\text { maternal pre-eclampsia } \\
\text { or eclampsia, neonatal } \\
\text { jaundice, severe } \\
\text { prematurity, twin, and } \\
\text { birth weight }\end{array}$ \\
\hline & & & & & & & $\leq 32$ & $3.96(1.46-10.81)$ & \\
\hline & {$[33]^{b}$} & 1998 & PCC & 502 & 433 & USA & $\geq 43$ & $1.5(0.8-2.6)$ & Crude ORs \\
\hline & & & & & & & $37-42$ & Referent & \\
\hline & & & & & & & $\leq 36$ & $0.9(0.5-1.8)$ & \\
\hline & {$[15]^{a, b}$} & 2000 & LCC & 480 & 2,854 & USA & $\geq 37$ & Referent & Crude ORs \\
\hline & & & & & & & $33-36$ & $1.34(0.85-2.13)$ & \\
\hline & & & & & & & $\leq 32$ & $0.55(0.19-1.57)$ & \\
\hline & {$[34]^{a, b}$} & 2001 & LCC & 87 & 87 & Sweden & $\geq 40$ & $8.4(1.3-54.4)$ & $\begin{array}{l}\text { Matched analysis by } \\
\text { conditional logistic } \\
\text { regression }\end{array}$ \\
\hline & & & & & & & $37-40$ & $3.4(0.7-17.0)$ & \\
\hline & & & & & & & $33-36$ & $3.5(0.7-17.5)$ & \\
\hline & & & & & & & $\leq 32$ & Referent & \\
\hline & {$[25]^{a}$} & 2003 & LCohort & 127 & $(1,483)$ & Sweden & $\geq 33$ & $1.08(0.64-1.70)$ & $\begin{array}{l}\text { Standardized incidence } \\
\text { ratio (expected/ } \\
\text { observed) }\end{array}$ \\
\hline & & & & & & & $\leq 32$ & $0.92(0.57-1.41)$ & \\
\hline & {$[45]^{a, b}$} & 2004 & LCC & 2,471 & 9,801 & USA & $\geq 37$ & Referent & $\begin{array}{l}\text { Adjusted for age and } \\
\text { maternal age at first } \\
\text { birth }\end{array}$ \\
\hline & & & & & & & $32-36$ & $0.91(0.72-1.13)$ & \\
\hline & & & & & & & $\leq 31$ & $1.43(0.90-2.28)$ & \\
\hline
\end{tabular}


Table 5 Studies assessing the association of premature birth and the risk of breast cancer

\begin{tabular}{|c|c|c|c|c|c|c|c|c|c|}
\hline & {$[20]^{\mathrm{b}}$} & 2005 & PCC & 1,424 & 1,457 & Poland & $\geq 37$ & Referent & $\begin{array}{l}\text { Adjusted for age, } \\
\text { education, age at } \\
\text { menarche, menopausal } \\
\text { status and age at } \\
\text { menopause, age at first } \\
\text { full-term pregnancy, } \\
\text { number of full-term } \\
\text { pregnancies, family } \\
\text { history of breast cancer } \\
\text { among first-degree } \\
\text { relatives, mammography } \\
\text { screening, and current } \\
\text { body mass index }\end{array}$ \\
\hline & & & & & & & $\leq 36$ & $1.01(0.75-1.32)$ & \\
\hline \multirow[t]{17}{*}{$\begin{array}{l}\text { Cohort } \\
\text { studies }\end{array}$} & {$[62]^{c}$} & 2000 & LCohort & 12 & 273 & Sweden & 35 & $0.2(0.01-1.3)$ & $\begin{array}{l}\text { Standardized incidence } \\
\text { ratio }\end{array}$ \\
\hline & & & & & & & $33-34$ & $0.7(0.1-2.0)$ & \\
\hline & & & & & & & $31-32$ & $2.3(0.7-5.3)$ & \\
\hline & & & & & & & $<31$ & $6.7(1.4-19.5)$ & \\
\hline & {$[16]^{\mathrm{c}}$} & 2001 & LTCCS & 2,265 & 9,060 & Sweden & $33-36$ & Referent & Crude ORs \\
\hline & & & & & & & $37-38$ & $1.8(0.83-4.0)$ & \\
\hline & & & & & & & $40-44$ & $2.0(0.88-4.6)$ & \\
\hline & {$[29]^{c}$} & 2005 & LCohort & 367 & 5,346 & Sweden & 1 week increase & $<50$ years & \\
\hline & & & & & & & & $0.94(0.83-1.07)$ & \\
\hline & {$[40]^{c}$} & 2006 & Cohort & 97 & 5,847 & USA & $<39$ & $0.77(0.42-1.4)$ & Adjusted for age \\
\hline & & & & & & & 39 & $1.38(0.78-2.4)$ & \\
\hline & & & & & & & 40 & Referent & \\
\hline & & & & & & & $41+$ & $1.33(0.67-2.6)$ & \\
\hline & {$[31]^{b}$} & 2006 & Cohort & 249 & 1024 & USA & $\geq 43$ & $0.7(0.2-2.7)$ & $\begin{array}{l}\text { Adjusted for: age at } \\
\text { diagnosis, diagnosis } \\
\text { year, stage at diagnosis, } \\
\text { and birth order, with } \\
\text { exception of birth order, } \\
\text { which is adjusted for } \\
\text { maternal age }\end{array}$ \\
\hline & & & & & & & $37-42$ & Referent & \\
\hline & & & & & & & $<37$ & $1.4(0.7-2.9)$ & \\
\hline & & & & & & & & $P$ for trend $=0.3$ & \\
\hline
\end{tabular}

Cohort, cohort study; LCC, case-control study with linkage with population and cancer registry data; LTCCS, twin case-control study by using linkage with birth and cancer registry data; NCC, nested case-control study in cohort; PCC, population-based case-control study. aWe included this study in the meta-analysis with categories of $\geq 33$ versus $\leq 32$ months (reference). bWe included this study in the meta-analysis with categories of $\geq 37$ versus $\leq 36$ months (reference). cWe did not include these studies in the meta-analysis because they employed different categories or a continuous scale, or they did not provide the numbers of cases and controls in the report. 
Breast Cancer Research Vol 10 No 1 Park et al.

Table 6

Studies assessing the association of twinship with risk for breast cancer

\begin{tabular}{|c|c|c|c|c|c|c|c|c|c|}
\hline $\begin{array}{l}\text { Type of } \\
\text { study }\end{array}$ & Ref. & Year & Design & Cases & $\begin{array}{l}\text { Controls } \\
\text { (or cohort) }\end{array}$ & $\begin{array}{l}\text { Country/ } \\
\text { place of study }\end{array}$ & Category & OR $(95 \% \mathrm{Cl})$ & Comments \\
\hline \multirow[t]{24}{*}{$\begin{array}{l}\text { Case- } \\
\text { control } \\
\text { studies }\end{array}$} & {$[63]^{a}$} & 1992 & MCC & 870 & $2,741 S$ & UK, USA & Singleton & Referent & $\begin{array}{l}\text { Adjusted for age, study } \\
\text { center, parity, age at first } \\
\text { birth, age at menarche, } \\
\text { height, body mass index, } \\
\text { maternal age at birth, } \\
\text { birth order, and } \\
\text { menopausal status }\end{array}$ \\
\hline & & & & & & & Twinship & $1.40(0.77-2.55)$ & \\
\hline & & & & & & & Singleton & Referent & \\
\hline & & & & & & & Monozygote twin & $1.30(0.58-2.92)$ & \\
\hline & & & & & & & Dizygote twin & $1.54(0.64-3.71)$ & \\
\hline & {$[14]$} & 1996 & PCC & 1,134 & 1,380 & USA & Age $21-45$ & & $\begin{array}{l}\text { Adjusted for age, } \\
\text { menopausal status, and } \\
\text { maternal smoking }\end{array}$ \\
\hline & & & & & & & Singleton & Referent & \\
\hline & & & & & & & Twinship & $0.6(0.3-1.3)$ & \\
\hline & & & & & & & Age $50-64$ & & \\
\hline & & & & & & & Singleton & Referent & \\
\hline & & & & & & & Twinship & $0.9(0.4-2.2)$ & \\
\hline & {$[58]^{a}$} & 1997 & PCC & 2,150 & 1,961 & USA & Singleton & Referent & $\begin{array}{l}\text { Adjusted for age, study } \\
\text { site, family history of } \\
\text { breast cancer, breast } \\
\text { biopsy, a combination } \\
\text { variable including } \\
\text { number of full-term } \\
\text { births and age at first } \\
\text { full-term pregnancy, age } \\
\text { at menarche, } \\
\text { menopausal status, } \\
\text { body mass index, } \\
\text { average lifetime alcohol } \\
\text { consumption, and the } \\
\text { number of } \\
\text { mammograms }\end{array}$ \\
\hline & & & & & & & Twinship & $1.6(1.0-2.7)$ & \\
\hline & & & & & & & Singleton & Referent & \\
\hline & & & & & & & Monozygote twin & $1.39(0.7-2.6)$ & \\
\hline & & & & & & & Dizygote twin & $2.06(1.0-4.5)$ & \\
\hline & [32] & 1997 & NCC & 1,068 & 2,727 & Sweden & Singleton & Referent & $\begin{array}{l}\text { Adjusted for maternal } \\
\text { age, matermal } \\
\text { socioeconomic status, } \\
\text { maternal parity, maternal } \\
\text { pre-eclampsia or } \\
\text { eclampsia, neonatal } \\
\text { jaundice, severe } \\
\text { prematurity, twin, and } \\
\text { birth weight }\end{array}$ \\
\hline & & & & & & & Twinship & $1.3(0.8-2.1)$ & \\
\hline & & & & & & & Singleton & Referent & \\
\hline & & & & & & & Monozygote twin & $0.7(0.2-2.2)$ & \\
\hline & & & & & & & Dizygote twin & $1.5(0.8-2.7)$ & \\
\hline & {$[15]$} & 2000 & LCC & 481 & 2,863 & USA & Singleton & Referent & Crude ORs \\
\hline & & & & & & & Twinship & $1.04(0.51-2.11)$ & \\
\hline & [43] & 2001 & LCC & 319 & 768 & USA & Singleton & Referent & Crude ORs \\
\hline
\end{tabular}




\section{Studies assessing the association of twinship with risk for breast cancer}

\begin{tabular}{|c|c|c|c|c|c|c|c|c|c|}
\hline & \multirow[b]{2}{*}{ [45] } & \multirow[b]{2}{*}{2004} & \multirow[b]{2}{*}{ LCC } & \multirow[b]{2}{*}{2,522} & \multirow[b]{2}{*}{10,052} & \multirow[b]{2}{*}{ USA } & \multirow{2}{*}{$\begin{array}{l}\text { Twinship } \\
\text { Singleton }\end{array}$} & \multicolumn{2}{|l|}{$1.6(0.2-10.1)$} \\
\hline & & & & & & & & Referent & $\begin{array}{l}\text { Adjusted for age and } \\
\text { maternal age at first } \\
\text { birth }\end{array}$ \\
\hline & & & & & & & Twinship & $1.77(1.05-2.97)$ & \\
\hline & [20] & 2005 & PCC & 2,338 & 2,476 & Poland & Singleton & Referent & $\begin{array}{l}\text { Adjusted for age, } \\
\text { education, age at } \\
\text { menarche, menopausal } \\
\text { status and age at } \\
\text { menopause, age at first } \\
\text { full-term pregnancy, } \\
\text { number of full-term } \\
\text { pregnancy, family history } \\
\text { of breast cancer among } \\
\text { first-degree relatives, } \\
\text { mammography } \\
\text { screening, and current } \\
\text { body mass index }\end{array}$ \\
\hline & & & & & & & Twinship & $0.76(0.49-1.16)$ & \\
\hline & & & & & & & Singleton & Referent & \\
\hline & & & & & & & Monozygote twin & $0.90(0.53-1.52)$ & \\
\hline & & & & & & & Dizygote twin & $0.58(0.23-1.47)$ & \\
\hline \multirow[t]{14}{*}{$\begin{array}{l}\text { Cohort } \\
\text { studies }\end{array}$} & [64] & 1980 & LTCohort & 270 & $(16,922)$ & Denmark & Twinship & $1.1(1.0-1.2)$ & $\begin{array}{l}\text { Observed/expected } \\
\text { ratio }(95 \% \mathrm{Cl})\end{array}$ \\
\hline & [65] & 1995 & LTCohort & 740 & $(25,541)$ & Sweden & Twinship & $1.1(1.0-1.1)$ & $\begin{array}{l}\text { Observed/expected } \\
\text { ratio }(95 \% \mathrm{Cl})\end{array}$ \\
\hline & & & & & & & Monozygote twin & $1.0(0.9-1.2)$ & \\
\hline & & & & & & & Dizygote twin & $1.1(1.0-1.2)$ & \\
\hline & [67] & 1999 & LTCohort & 245 & $(13,176)$ & Finland & Twinship & $0.91(0.81-1.00)$ & $\begin{array}{l}\text { Observed/expected } \\
\text { ratio }(95 \% \mathrm{Cl})\end{array}$ \\
\hline & & & & & & & Monozygote twin & $0.76(0.59-0.97)$ & \\
\hline & & & & & & & Dizygote twin & $0.98(0.84-1.10)$ & \\
\hline & [66] & 2000 & Cohort & 1,230 & $(29,197)$ & USA & Singleton & Referent & $\begin{array}{l}\text { Adjusted for age, } \\
\text { education, family history } \\
\text { of breast cancer, age at } \\
\text { menarche, age at first } \\
\text { birth, height, current } \\
\text { body mass index, body } \\
\text { mass index at age } 18, \\
\text { waist:hip ratio, alcohol } \\
\text { drinking, and hormone } \\
\text { replacement therapy }\end{array}$ \\
\hline & & & & & & & Twinship & $1.72(1.22-2.42)$ & \\
\hline & & & & & & & Singleton & Referent & \\
\hline & & & & & & & Monozygote twin & $1.04(0.43-2.5)$ & \\
\hline & & & & & & & Dizygote twin & $1.77(1.16-2.7)$ & \\
\hline & [31] & 2006 & Cohort & 249 & 1,024 & USA & Singleton & Referent & $\begin{array}{l}\text { Adjusted for age at } \\
\text { diagnosis, diagnosis } \\
\text { year, stage at diagnosis, } \\
\text { and birth order, with } \\
\text { exception of birth order, } \\
\text { which is adjusted for } \\
\text { maternal age }\end{array}$ \\
\hline & & & & & & & Twinship & $2.5(1.0-6.2)$ & \\
\hline
\end{tabular}

aAuthors used the female twins as the proxy of the monozygote twin and the female twin with male twin as the proxy of the dizygote twin. Cohort, cohort study; LCC, case-control study with linkage with population and cancer registry data; LTCohort, twin cohort study by using linkage with birth and cancer registry data; MCC, multicenter case-control study; NCC, nested case-control study in cohort; PCC, population-based casecontrol study. 
Breast Cancer Research Vol 10 No 1 Park et al.

Table 7

Studies assessing the association of maternal or paternal smoking and the risk of breast cancer

\begin{tabular}{|c|c|c|c|c|c|c|c|c|c|}
\hline $\begin{array}{l}\text { Type of } \\
\text { study }\end{array}$ & Ref. & Year & Design & Cases & $\begin{array}{l}\text { Controls } \\
\text { (or cohort) }\end{array}$ & $\begin{array}{l}\text { Country/ } \\
\text { place of study }\end{array}$ & Smoking status & OR $(95 \% \mathrm{Cl})$ & Comments \\
\hline \multirow{25}{*}{$\begin{array}{l}\text { Case- } \\
\text { control } \\
\text { studies }\end{array}$} & [69] & 1996 & PCC & 53 & 470 & USA & $\begin{array}{l}\text { Maternal } \\
\text { smoking }\end{array}$ & & Crude ORs \\
\hline & & & & & & & No & Referent & \\
\hline & & & & & & & Yes & $0.9(0.4-2.1)$ & \\
\hline & & & & & & & $\begin{array}{l}\text { Paternal } \\
\text { smoking }\end{array}$ & & \\
\hline & & & & & & & No & Referent & \\
\hline & & & & & & & Yes & $1.3(0.9-1.7)$ & \\
\hline & {$[14]$} & 1996 & PCC & 1,086 & 1,321 & USA & $\begin{array}{l}\text { Maternal } \\
\text { smoking }\end{array}$ & & $\begin{array}{l}\text { Adjusted for age, } \\
\text { menopausal status, and } \\
\text { maternal smoking; OR }(95 \% \\
\text { Cl) for maternal smoking } \\
\text { among early-onset breast } \\
\text { cancer patients }(\leq 30 \text { years } \\
\text { old) was } 1.9(1.0-3.4)\end{array}$ \\
\hline & & & & & & & $\begin{array}{l}\text { Age 21-45 } \\
\text { years }\end{array}$ & & \\
\hline & & & & & & & No & Referent & \\
\hline & & & & & & & Yes & $1.1(0.9-1.3)$ & \\
\hline & & & & & & & $\begin{array}{l}\text { Age } 50-64 \\
\text { years }\end{array}$ & & \\
\hline & & & & & & & No & Referent & \\
\hline & & & & & & & Yes & $1.3(0.9-2.1)$ & \\
\hline & {$[58]$} & 1997 & PCC & 522 & 484 & USA & $\begin{array}{l}\text { Maternal } \\
\text { smoking }\end{array}$ & & $\begin{array}{l}\text { Adjusted for age, study site, } \\
\text { family history of breast } \\
\text { cancer, breast biopsy, a } \\
\text { combination variable } \\
\text { including number of full-term } \\
\text { births and age at first full- } \\
\text { term pregnancy, age at } \\
\text { menarche, menopausal } \\
\text { status, body mass index, } \\
\text { average lifetime alcohol } \\
\text { consumption, and the } \\
\text { number of mammograms }\end{array}$ \\
\hline & & & & & & & No & Referent & \\
\hline & & & & & & & Yes & $1.1(0.8-1.4)$ & \\
\hline & [33] & 1998 & PCC & 507 & 433 & USA & $\begin{array}{l}\text { Maternal } \\
\text { smoking }\end{array}$ & & Crude ORs \\
\hline & & & & & & & No & Referent & \\
\hline & & & & & & & Yes & $1.1(0.9-1.5)$ & \\
\hline & [43] & 2001 & LCC & 319 & 768 & USA & $\begin{array}{l}\text { Maternal } \\
\text { smoking }\end{array}$ & & Adjusted for attained age \\
\hline & & & & & & & No & Referent & \\
\hline & & & & & & & Yes & $2.7(1.1-6.3)$ & \\
\hline & {$[35]^{\mathrm{a}}$} & 2002 & PCC & 1,535 & 1,534 & USA & Smoking & & $\begin{array}{l}\text { Adjusted for age and } \\
\text { residential regions (states) }\end{array}$ \\
\hline & & & & & & & No & Referent & \\
\hline & & & & & & & $\begin{array}{l}\text { Paternal } \\
\text { smoking }\end{array}$ & $1.00(0.88-1.13)$ & \\
\hline
\end{tabular}


Studies assessing the association of maternal or paternal smoking and the risk of breast cancer

\begin{tabular}{|c|c|c|c|c|c|c|c|c|c|}
\hline & & & & & & & $\begin{array}{l}\text { Maternal/ } \\
\text { parental } \\
\text { smoking }\end{array}$ & $1.10(0.84-1.42)$ & \\
\hline & [20] & 2005 & PCC & 2380 & 2,497 & Poland & $\begin{array}{l}\text { Maternal } \\
\text { smoking }\end{array}$ & & Unadjusted; recalculated \\
\hline & & & & & & & No & Referent & \\
\hline & & & & & & & $\begin{array}{l}\text { Yes (any } \\
\text { exposure) }\end{array}$ & $1.19(0.97-1.47)$ & \\
\hline & & & & & & & $\begin{array}{l}\text { Paternal } \\
\text { smoking }\end{array}$ & & \\
\hline & & & & & & & No & Referent & \\
\hline & & & & & & & $\begin{array}{l}\text { Yes (any } \\
\text { exposure) }\end{array}$ & $0.90(0.77-1.05)$ & \\
\hline \multirow[t]{8}{*}{$\begin{array}{l}\text { Cohort } \\
\text { studies }\end{array}$} & [31] & 2006 & Cohort & 249 & 1,024 & USA & $\begin{array}{l}\text { Maternal } \\
\text { smoking }\end{array}$ & Referent & $\begin{array}{l}\text { Adjusted for age at } \\
\text { diagnosis, diagnosis year, } \\
\text { stage at diagnosis, and birth } \\
\text { order, with exception of birth } \\
\text { order, which is adjusted for } \\
\text { maternal age Crude relative } \\
\text { rates }\end{array}$ \\
\hline & & & & & & & No & $0.8(0.5-1.1)$ & \\
\hline & & & & & & & $\begin{array}{l}\text { Yes (any } \\
\text { exposure) }\end{array}$ & & \\
\hline & [68] & 2005 & Cohort & 42 & $(3,989)$ & USA & $\begin{array}{l}\text { Maternal } \\
\text { smoking }\end{array}$ & & \\
\hline & & & & & & & No & Referent & \\
\hline & & & & & & & $\begin{array}{l}\text { Yes (any } \\
\text { exposure) }\end{array}$ & $0.49(0.29-1.03)$ & \\
\hline & & & & & & & $\begin{array}{l}\leq 15 \\
\text { cigarettes a } \\
\text { day }\end{array}$ & $0.33(0.12-0.94)$ & \\
\hline & & & & & & & $>15$ & $0.68(0.26-1.73)$ & \\
\hline
\end{tabular}

aTitus-Ernstoff and coworkers [35] classified three categories: nonparental smoking, either paternal or maternal smoking only or both parents smoking during pregnancy. Thus, in this study, the maternal or both parents smoking versus nonparental smoking can be regarded as maternal smoking versus no maternal smoking. Cohort, cohort study; LCC, case-control study by linkage with population data and cancer registry data; PCC, population-based case-control study. 


\section{Acknowledgements}

This research was supported, in part, by the Intramural Research Program of the National Institutes of Health (National Cancer Institute).

\section{References}

1. Trichopoulos D: Hypothesis: does breast cancer originate in utero? Lancet 1990, 335:939-40.

2. Tulchinsky D, Hobel $\mathrm{CH}$, Yeager E, Marshall JR: Plasma estrone, estradiol, estriol, progesterone and 17-hydroxyprogesterone in human pregnancy: I. Normal pregnancy. Am J Obstet Gynecol 1972, 112:1095-1100.

3. Buster JE, Sakakini J Jr, Killam AP, Scragg WH: Serum unconjugated estriol levels in the third trimester and their relationship to gestational age. Am J Obstet Gynecol 1976, 125:672-676.

4. Lindberg BS, Johansson EDB, Nilsson BA: Plasma levels of nonconjugated estrone, estradiol, $17 \beta$, and estriol during uncomplicated pregnancy. Acta Obstet Gynecol Scand Suppl 1974, 32:21-36.

5. Trichopoulos D: Intrauterine environment, mammary gland mass and breast cancer risk. Breast Cancer Res 2003, 5:42-44.

6. Potischman N, Troisi R: In-utero and early life exposures in relation to risk of breast cancer. Cancer Causes Control 1999, 10:561-573.

7. Grotmol T, Weiderpass E, Tretli S: Conditions in utero and cancer risk. Eur J Epidemiol 2006, 21:561-570.

8. Hardy RJ, Thompson SG: Detecting and describing heterogeneity in meta-analysis. Stat Med 1998, 17:841-856.

9. Begg $\mathrm{CB}$, Mazumdar M: Operating characteristics of a rank correlation test for publication bias. Biometrics 1994, 50:1088-1101.

10. Egger M, Davey SG, Schneider M, Minder C: Bias in meta-analysis detected by a simple, graphical test. BMJ 1997, 315:629-634

11. Macaskill $P$, Walter SD, Irwig L: A comparison of methods to detect publication bias in meta-analysis. Stat Med 2001, 20:641-654.

12. Ekbom A, Trochopoulos D, Adami HO, Hsieh CC, Land SJ: Evidence of prenatal influences on breast cancer risk. Lancet 1992, 340:1015-1018.

13. Michels KB, Trichopoulos D, Robins JM, Rosner BA, Manson JE, Hunter DJ, Colditz GA, Hankinson SE, Speizer FE, Willett WC: Birth weight as a risk factor for breast cancer. Lancet 1996, 348:1542-1546.

14. Sanderson M, Williams MA, Malone KE, Stanford JL, Emanuel I, White E, Daling JR: Perinatal factors and risk of breast cancer. Epidemiology 1996, 7:34-37.

15. Innes K, Byers T, Schymura M: Birth characteristics and subsequent risk for breast cancer in very young women. $A m \mathrm{~J}$ Epidemiol 2000, 152:1121-1128.

16. Kaijser M, Lichtenstein P, Granath F, Erlandsson G, Cnattingius S, Ekbom A: In utero exposures and breast cancer: a study of opposite-sexed twins. J Natl Cancer Inst 2001, 93:60-62.

17. Vatten LJ, Maehle BO, Lund Nilsen TI, Tretli S, Hsieh CC, Trichopoulos D, Stuver SO: Birth weight as a predictor of breast cancer: a case-control study in Norway. Br J Cancer 2002, 86:89-91.

18. Mellemkjaer L, Olsen ML, Sorensen HT, Thulstrup AM, Olsen J, Olsen JH: Birth weight and risk of early-onset breast cancer (Denmark). Cancer Causes Control 2003, 14:61-64.

19. Lahmann $\mathrm{PH}$, Gullberg B, Olsson $\mathrm{H}$, Boeing $\mathrm{H}$, Berglund $\mathrm{G}$, Lissner $\mathrm{L}$ : Birth weight is associated with postmenopausal breast cancer risk in Swedish women. $\mathrm{Br} J$ Cancer 2004, 91:1666-1668.

20. Park SK, Garcia-Closas M, Lissowska J, Sherman ME, McGlynn KA, Peponska B, Bardin-Mikoajczak A, Zatonski W, SzeszeniaDabrowska N, Brinton LA: Intrauterine environment and breast cancer risk in a population-based case-control study in Poland. Int J Cancer 2006, 119:2136-2141.

21. Mogren I, Damber L, Tavelin B, Hogberg U: Characteristics of pregnancy and birth and malignancy in the offspring (Sweden). Cancer Causes Control 1999, 10:85-94.

22. De Stavola BL, Hardy R, Kuh D, Silva IS, Wadsworth M, Swerdlow AJ: Birthweight, childhood growth and risk of breast cancer in a British cohort. Br J Cancer 2000, 83:964-968.
23. McCormack VA, dos Santos Silva I, De Stavola BL, Mohsen R, Leon DA, Lithell HO: Fetal growth and subsequent risk of breast cancer: results from long term follow up of Swedish cohort. BMJ 2003, 326:248.

24. Ahlgren M, Sorensen T, Wohlfahrt J, Haflidadottir A, Holst C, Melbe M: Birth weight and risk of breast cancer in a cohort of 106,504 women. Int J Cancer 2003, 107:997-1000.

25. Kaijser M, Akre O, Cnattinguis S, Ekbom A: Preterm birth, birth weight, and subsequent risk of female breast cancer. $\mathrm{Br} J$ Cancer 2003, 89:1664-1666.

26. Ahlgren M, Melbye M, Wohlfahrt J, Sorensen TI: Growth patterns and the risk of breast cancer in women. N Engl J Med 2004, 351:1619-1626.

27. dos Santos Silva I, De Stavola BL, Hardy RJ, Kuh DJ, McCormack VA, Wadsworth ME: Is the association of birth weight with premenopausal breast cancer risk mediated through childhood growth? Br J Cancer 2004, 91:519-524.

28. Vatten LJ, Nilsen TI, Tretli S, Trichopoulos D, Romundstad PR: Size at birth and risk of breast cancer: prospective populationbased study. Int J Cancer 2005, 114:461-464.

29. McCormack VA, dos Santos Silva I, Koupil I, Leon DA, Lithell HO Birth characteristics and adult cancer incidence: Swedish cohort of over 11,000 men and women. Int J Cancer 2005, 115:611-7.

30. Michels KB, Xue F, Terry KL, Willett WC: Longitudinal study of birthweight and the incidence of breast cancer in adulthood. Carcinogenesis 2006, 27:2464-2468.

31. Sanderson M, Daling JR, Doody DR, Malone KE: Perinatal factors and mortality from breast cancer. Cancer Epidemiol Biomarkers Prev 2006, 15:1984-1987.

32. Ekbom A, Hsieh CC, Lipworth L, Adami HQ, Trichopoulos D: Intrauterine environment and breast cancer risk in women: a population-based study. J Nat/ Cancer Inst 1997, 89:71-76.

33. Sanderson M, Williams MA, White E, Daling JR, Holt VL, Malone $\mathrm{KE}$, Self SG, Moore DE: Validity and reliability of subject and mother reporting of perinatal factors. Am J Epidemiol 1998, 147:136-140.

34. Hubinette A, Lichtenstein P, Ekbom A, Cnattingius S: Birth characteristics and breast cancer risk: a study among like-sexed twins. Int J Cancer 2001, 91:248-251.

35. Titus-Ernstoff L, Egan KM, Newcomb PA, Ding J, Trentham-Dietz A, Greenberg ER, Baron JA, Trichopoulos D, Willett WC: Early life factors in relation to breast cancer risk in postmenopausal women. Cancer Epidemiol Biomarkers Prev 2002, 11:207-210.

36. Hodgson ME, Newman B, Millikan RC: Birth weight, parental age, birth order and breast cancer risk in African-American and white women: a population-based case-control study. Breast Cancer Res 2004, 6:R656-R667.

37. Barba M, McCann SE, Nie J, Vito D, Stranges S, Fuhrman B, Trevisan M, Muti $P$, Freudenheim JL: Perinatal exposures and breast cancer risk in the Western New York Exposures and Breast Cancer (WEB) Study. Cancer Causes Control 2006, 17:395-401

38. Hilakivi-Clarke L, Forsen T, Eriksson JG, Luoto R, Tuomilehto J, Osmond C, Barker DJ: Tallness and overweight during childhood have opposing effects on breast cancer risk. $\mathrm{Br} J$ Cancer 2001, 85:1680-1684.

39. Andersson SW, Bengtsson C, Hallberg L, Lapidus L, Niklasson A, Wallgren $A$, Hulthen $L$ : Cancer risk in Swedish women: the relation to size at birth. $\mathrm{Br} J$ Cancer 2001, 84:1193-1198.

40. Troisi R, Hatch EE, Titus-Ernstoff L, Palmer JR, Hyer M, Strohsnitter WC, Robboy SJ, Kaufman R, Herbst A, Adam E, Hoover RN: Birth weight and breast cancer risk. $\mathrm{Br} J$ Cancer 2006, 94:1734-1737.

41. Lof M, Sandin S, Hilakivi-Clarke L, Weiderpass E: Birth weight in relation to endometrial and breast cancer risks in Swedish women. Br J Cancer 2007, 96:134-136.

42. Le Marchand L, Kolonel LN, Myers BC, Mi MP: Birth characteristics of premenopausal women with breast cancer. $\mathrm{Br} J$ Cancer 1988, 57:437-439.

43. Innes KE, Byers TE: Smoking during pregnancy and breast cancer risk in very young women (United States). Cancer Causes Control 2001, 12:179-185.

44. Sanderson M, Shu XO, Jin F, Dai Q, Ruan Z, Gao YT, Zheng W: Weight at birth and adolescence and premenopausal breast cancer risk in a low-risk population. $\mathrm{Br} J$ Cancer 2002 86:84-88. 
45. Innes KE, Byers TE: First pregnancy characteristics and subsequent breast cancer risk among young women. Int J Cancer 2004, 112:306-311.

46. Hsieh CC, Tzonou A, Trichopoulos D: Birth order and breast cancer risk. Cancer Causes Control 1991, 2:95-98.

47. Janerich DT, Thompson WD, Mineau GP: Maternal pattern of reproduction and risk of breast cancer in daughters: results from the Utah Population Database. J Natl Cancer Inst 1994, 86:1634-1639.

48. Okobia MN, Bunker CH, Lee LL, Osime U, Uche EE: Case-control study of risk factors for breast cancer in Nigerian women: a pilot study. East Afr Med J 2005, 82:14-19.

49. Hemminki K, Mutanen P: Birth order, family size, and the risk of cancer in young and middle-aged adults. Br J Cancer 2001, 84:1466-1471.

50. Rothman KJ, MacMahon B, Lin TM, Lowe CR, Mirra AP, Ravnihar B, Salber EJ, Trichopoulos D, Yuasa S: Maternal age and birth rank of women with breast cancer. J Natl Cancer Inst 1980, 65:719-722.

51. Standfast SJ: Birth characteristics of women dying from breast cancer. J Natl Cancer Inst 1967, 39:33-42.

52. Janerich DT, Hayden CL, Thompson WD, Selenskas SL, Mettlin C: Epidemiologic evidence of perinatal influence in the etiology of adult cancers. J Clin Epidemiol 1989, 42:151-157.

53. Baron JA, Vessey M, McPherson K, Yeates D: Maternal age and breast cancer risk. J Natl Cancer Inst 1984, 72:1307-1309.

54. Thompson WD, Janerich DT: Maternal age at birth and risk of breast cancer in daughters. Epidemiology 1990, 1:101-106.

55. Colditz GA, Willett WC, Stampfer MJ, Hennekens CH, Rosner B, Speizer FE: Parental age at birth and risk of breast cancer in daughters: a prospective study among US women. Cancer Causes Control 1991, 2:31-36.

56. Choi JY, Lee KM, Park SK, Noh DY, Ahn SH, Yoo KY, Kang D: Association of paternal age at birth and the risk of breast cancer in offspring: a case control study. BMC Cancer 2005, $5: 143$.

57. Newcomb PA, Trentham-Dietz A, Storer BE: Parental age in relation to risk of breast cancer. Cancer Epidemiol Biomarkers Prev 1997, 6:151-154.

58. Weiss HA, Potischman NA, Brinton LA Brogan D, Coates RJ, Gammon MD, Malone KE, Schoenberg JB: Prenatal and perinatal risk factors for breast cancer in young women. Epidemiology 1997, 8:181-187.

59. Zhang Y, Cupples LA, Rosenberg L, Colton T, Kreger BE: Parental ages at birth in relation to a daughter's risk of breast cancer among female participants in the Framingham Study (United States). Cancer Causes Control 1995, 6:23-29.

60. Holmberg L, Ekbom A, Calle E, Mokdad A, Byers T: Parental age and breast cancer mortality. Epidemiology 1995, 6:425-427.

61. Henderson BE, Powell D, Rosario I, Keys C, Hanisch R, Young M, Casagrande J, Gerkins V, Pike MC: An epidemiologic study of breast cancer. I Natl Cancer Inst 1974, 53:609-614.

62. Ekbom A, Erlandsson G, Hsieh C, Trichopoulos D, Adami HO, Cnattingius S: Risk of breast cancer in prematurely born women. J Natl Cancer Inst 2000, 92:840-841.

63. Hsieh CC, Lan SJ, Ekbom A, Petridou E, Adami HO, Trichopoulos $\mathrm{D}$ : Twin membership and breast cancer risk. Am J Epidemiol 1992, 136:1321-1326.

64. Holm NV, Hauge M, Harvald B: Etiologic factors of breast cancer elucidated by a study of unselected twins. I Natl Cancer Inst 1980, 65:285-298.

65. Braun MM, Ahlbom A, Floderus B, Brinton LA, Hoover RN: Effect of twinship on incidence of cancer of the testis, breast, and other sites (Sweden). Cancer Causes Control 1995, 6:519-524.

66. Cerhan JR, Kushi LH, Olson JE, Rich SS, Zheng W, Folsom AR, Sellers TA: Twinship and risk of postmenopausal breast cancer. J Natl Cancer Inst 2000, 92:261-265.

67. Verkasalo PK, Kaprio J, Pukkala E, Koskenvuo M: Breast cancer risk in monozygotic and dizygotic female twins: a 20-year population-based cohort study in Finland from 1976 to 1995 . Cancer Epidemiol Biomarkers Prev 1999, 8:271-274.

68. Strohsnitter WC, Noller KL, Titus-Ernstoff L, Troisi R, Hatch EE, Poole C, Glynn RJ, Hsieh CC: Breast cancer incidence in women prenatally exposed to maternal cigarette smoke. Epidemiology 2005, 16:342-345.
69. Sandler DP, Everson RB, Wilcox AJ, Browder JP: Cancer risk in adulthood from early life exposure to parents' smoking. Am J Public Health 1985, 75:487-492.

70. Michels KB, Xue F: Role of birthweight in the etiology of breast cancer. Int J Cancer 2006, 119:2007-2025.

71. Ahlgren M, Wohlfahrt J, Olsen LW, Sørensen TI, Melbye M: Birth weight and risk of cancer. Cancer 2007, 110:412-419.

72. Kaijser M, Granath F, Jacobsen G, Cnattingius S, Ekbom A: Maternal pregnancy estriol levels in relation to anamnestic and fetal anthropometric data. Epidemiology 2000, 11:315-319.

73. McFadyen IR, Worth HG, Wright DJ, Notta SS: High oestrogen excretion in pregnancy. $\mathrm{Br} J$ Obstet Gynaecol 1982, 89:994-999.

74. Mucci LA, Lagiou P, Tamimi RM, Hsieh CC, Adami HO, Trichopoulos D: Pregnancy estriol, estradiol, progesterone and prolactin in relation to birth weight and other birth size variables (United States). Cancer Causes Control 2003, 14:311-318.

75. Schernhammer ES: In-utero exposures and breast cancer risk: joint effect of estrogens and insulin-like growth factor? Cancer Causes Control 2002, 13:505-508.

76. Wang HS, Chard T: The role of insulin-like growth factor-I and insulin-like growth factor-binding protein-1 in the control of human fetal growth. J Endocrinol 1992, 132:11-19.

77. Savarese TM, Strohsnitter WC, Low HP, Liu Q, Baik I, Okulicz W, Chelmow DP, Lagiou P, Quesenberry P, Noller KL, Hsieh CC: Correlation of umbilical cord blood hormones and growth factors with stem cell potential: implications for the prenatal origin of breast cancer hypothesis. Breast Cancer Res 2007, 9:R29.

78. Troisi R, Potischman N, Roberts J, Siiteri P, Daftary A, Sims C, Hoover RN: Associations of maternal and umbilical cord hormone concentrations with maternal, gestational and neonatal factors (United States). Cancer Causes Control 2003, 14:347-355.

79. Vatten L, Romundstad PR, Ødegård RA, Nilsen ST, Trichopoulos $\mathrm{D}$, Austgulen R: a-Fetoprotein in umbilical cord in relation to severe preeclampsia, birth weight, and future breast cancer risk. Br J Cancer 2002, 86:728-731.

80. Nagata C, Iwasa S, Shiraki M, Shimizu H: Estrogen and alphafetoprotein levels in maternal and umbilical cord blood samples in relation to birth weight. Cancer Epidemiol Biomarkers Prev 2006, 15:1469-1472.

81. Panagiotopoulou K, Katsouyanni K, Petridou E, Garas Y, Tzonou A, Trichopoulos D: Maternal age, parity, and pregnancy estrogens. Cancer Causes Control 1990, 1:119-124.

82. Maccoby EE, Doering $\mathrm{CH}$, Nagy Jacklin $\mathrm{C}$, Kraemer $\mathrm{H}$ : Concentrations of sex hormones in umbilical-cord blood: their relation to sex and birth order of infants. Child Dev 1979, 50:632-642.

83. van Noord PAH: An alternative, non-intrauterine hypothesis, based on maternal mitochondrial oocyte inheritance, to explain inconsistent findings of birth weight on (breast) cancer risk. Br J Cancer 2003, 88:1817-1818.

84. Xue F, Colditz GA, Willett WC, Rosner BA, Michels KB: Parental age at delivery and incidence of breast cancer: a prospective cohort. study. Breast Cancer Res Treat 2007, 104:331-340.

85. Hemminki K, Kyyronen P: Parental age and risk of sporadic and familial cancer in offspring: implications for germ cell mutagenesis. Epidemiology 1999, 10:747-751.

86. Duff GB, Brown JB: Urinary oestriol excretion in twin pregnancies. J Obstet Gynaecol Br Commonw 1974, 81:695-700.

87. TambyRaja RL, Ratnam SS: Plasma steroid changes in twin pregnancies. Prog Clin Biol Res 1981, 69A:189-195.

88. Wald N, Cuckle H, Wu T, George L: Maternal serum unconjugated oestriol and human chorionic gonadotrophin levels in twin pregnancies: implications for screening for Down's syndrome. Br J Obstet Gynaecol 1991, 98:905-908.

89. Martin NG, El Beaini JL, Olsen ME, Bhatnagar AS, Macourt D: Gonadotropin levels in mothers who have had two sets of DZ twins. Acta Genet Med Gemellol (Roma) 1984, 33:131-139.

90. Campbell DM: Aetiology of twinning. In Twinning and twins Edited by: MacGillivray I, Campbell D, Thompson B. New York, NY: John Wiley \& Sons; 1988:27-36.

91. Petridou E, Panagiotopoulou K, Katsouyanni K, Spanos E, Trichopoulos D: Tobacco smoking, pregnancy estrogens, and birth weight. Epidemiology 1990, 1:247-250.

92. Bernstein L, Pike MC, Lobo RA, Depue RH, Ross RK, Henderson $\mathrm{B}$ : Cigarette smoking during pregnancy results in marked 
decrease in maternal HCG and oestradiol levels. $\mathrm{Br} J$ Obstet Gynaecol 1989, 96:92-96.

93. Ng SP, Steinetz BG, Lasano SG, Zelikoff JT: Hormonal changes accompanying cigarette smoke-induced preterm births in a mouse model. Exp Biol Med (Maywood) 2006, 231:1403-1409.

94. Jedrychowski W, Whyatt RM, Cooper TB, Flak E, Perera FP: Exposure misclassification error in studies on prenatal effects of tobacco smoking in pregnancy and the birth weight of children. J Expo Anal Environ Epidemiol 1998, 8:347-357.

95. Sanderson M, Williams MA, White E, Daling JR, Holt VL, Malone $\mathrm{KE}$, Self SG, Moore DE: Validity and reliability of subject and mother reporting of perinatal factors. Am J Epidemiol 1998, 147:136-140.

96. Torgersen S: The determination of twin zygosity by means of a mailed questionnaire. Acta Genet Med Gemellol (Roma) 1979, 28:225-236.

97. Lagiou P: Intrauterine exposures, pregnancy estrogens and breast cancer risk: where do we currently stand? Breast Cancer Res 2006, 8:112.

98. Palmer JR, Wise LA, Hatch EE, Troisi R, Titus-Ernstoff L, Strohsnitter W, Kaufman R, Herbst AL, Noller KL, Hyer M, Hoover RN: Prenatal diethylstilbestrol exposure and risk of breast cancer. Cancer Epidemiol Biomarkers Prev 2006, 15:1509-1514.

99. Trichopoulos D, Lagiou P, Adami HO: Towards an integrated model for breast cancer etiology: the crucial role of the number of mammary tissue-specific stem cells. Breast Cancer Res 2005, 7:13-17.

100. Hilakivi-Clarke L, de Assis S: Fetal origins of breast cancer. Trends Endocrinol Metab 2006, 17:340-348. 